Publisher: GSA

Journal: GEOL: Geology

DOI:10.1130/G36454.1

\title{
1 Glacio-isostatic control on hypoxia in a high-latitude shelf basin
}

2 Tom Jilbert ${ }^{1 *}$, Daniel J. Conley ${ }^{2}$, Bo G. Gustafsson ${ }^{3}$, Carolina P. Funkey ${ }^{2}$, and Caroline P.

3 Slomp ${ }^{1}$

$4 \quad{ }^{I}$ Department of Earth Sciences (Geochemistry), Faculty of Geosciences, Utrecht University, P.O.

5 Box 80.021, 3508 TA Utrecht, The Netherlands

$6 \quad{ }^{2}$ Department of Geology, Lund University, Sölvegatan 12, S-223 62 Lund, Sweden

$7 \quad{ }^{3}$ Baltic Nest Institute, Baltic Sea Centre, Stockholm University, S-106 91 Stockholm, Sweden

8 *Current address: Department of Environmental Sciences, P.O. Box 65, 00014 University of

9 Helsinki, Helsinki, Finland; tom.jilbert@ helsinki.fi

10 ABSTRACT

11 In high-latitude continental shelf environments, late-Pleistocene glacial overdeepening

12 and early Holocene eustatic sea-level rise combined to create restricted marine basins with a high

13 vulnerability to oxygen depletion. Here we show that ongoing glacio-isostatic rebound during the

14 Holocene may have played an important role in determining the distribution of past hypoxia in

15 these environments by controlling the physical exchange of water masses and the distribution of

16 large-scale phosphorus (P) sinks. We focus on the Baltic Sea, where sediment records from a

17 large, presently oxic sub-basin show evidence for intense hypoxia and cyanobacteria blooms

18 during the Holocene Thermal Maximum (HTM). Using paleobathymetric modeling, we show

19 that this period was characterized by enhanced deep-water exchange, allowing widespread

20 phosphorus regeneration. Intra-basin sills then shoaled over a period of several thousand years,

21 enhancing P burial in one of the sub-basins. Together with climate forcing, this may have caused

22 the termination of hypoxia throughout the Baltic Sea. Similar rearrangements of physical and 
Publisher: GSA

Journal: GEOL: Geology

DOI:10.1130/G36454.1

23 chemical processes likely occurred in response to glacio-isostatic rebound in other high-latitude

24 shelf basins during the Holocene.

\section{INTRODUCTION}

Restricted basins of the coastal oceans are vulnerable to oxygen depletion, being

27 frequently characterized by estuarine circulation and stagnation of deep water masses (Farmer

28 and Freeland, 1983). Understanding the conditions under which such basins become hypoxic is

29 crucial to understanding the role of natural versus anthropogenic processes in the present-day

30 expansion of coastal hypoxia (Diaz and Rosenberg, 2008) and the drivers of widespread burial of

31 organic carbon in the geologic past (Jarvis et al., 2011).

32 The eustatic transgression of the early Holocene created numerous restricted basins in the

33 modern ocean, ranging in scale from the Black Sea to fjord and lagoon systems across the full

34 latitudinal gradient. In particular, glacial erosion of high-latitude continental shelves during the

35 late Pleistocene led to the development of restricted basins during subsequent sea level rise (Fig.

36 1a). Overdeepening of bedrock topography by ice streams on the margins of major ice sheets

37 caused fjord formation in mountainous regions (Kessler et al., 2008) and the incision of $100 \mathrm{~m}$

38 scale 'deeps' in tectonic depressions such as the Baltic basin (Amantov et al., 2011) and the St.

39 Lawrence valley (Nota and Loring, 1964).

40 The modern Baltic Sea comprises a number of discrete sub-basins, centered on incised

41 deeps between intervening sills (Fig. 1b). The sub-basins are characterized by distinct oxygen

42 regimes (Fig. 1c), making the Baltic an ideal location to study the controls on hypoxia in shelf

43 basins. Water-mass stratification in the Baltic Proper is maintained by saline water inflows from

44 the North Sea, which stagnate in the deeps and become severely hypoxic and even euxinic (Fig.

45 1c). In contrast, the deep waters of the Bothnian Sea are oxic and relatively fresh, because the 
Publisher: GSA

Journal: GEOL: Geology

DOI:10.1130/G36454.1

46 sills of the Åland Sea are too shallow to allow exchange of deep waters from the Baltic Proper,

47 and because nutrient loading is more moderate in northern regions, leading to lower productivity

48 and oxygen demand (Lundberg et al., 2009).

49 Glacio-isostatic rebound after the retreat of the late Pleistocene ice sheets progressed

50 independently of eustatic sea level rise, leading to the continuous evolution of coastlines in the

51 high latitudes. During the deglaciation itself, freshwater and brackish phases occurred in the

52 Baltic basin (16-8.5 ka, Andrén et al., 2011), the St. Lawrence valley hosted the inland

53 Champlain Sea (13-9 ka, Cronin et al., 2008), and Hudson Bay experienced the Tyrrell Sea

54 marine invasion (8-6.5 ka, Bilodeau et al., 1990). Ongoing rebound after sea level stabilization

55 led to the closure of the Champlain Sea, the progressive isolation of the Baltic (Gustafsson and

56 Westman, 2002) and the shoaling of fjord basins in both hemispheres (Skei, 1988; Gallagher et

57 al., 1989). In this study we demonstrate the importance of glacio-isostasy to oxygen and nutrient

58 regimes in high-latitude shelf basins, using the Baltic Sea as a case study.

59 METHODS SUMMARY

60 Sediment Coring, Sampling and Chemical Analysis

61 Sediment cores were collected from sites LL19 in the Baltic Proper $\left(58.8807^{\circ}\right.$ N,

$6220.3108^{\circ} \mathrm{E}, 169 \mathrm{~m}$ water depth) and SR5 in the Bothnian Sea $\left(61.0833^{\circ} \mathrm{N}, 19.5797^{\circ} \mathrm{E}, 126 \mathrm{~m}\right.$

63 water depth) during cruises with R/V Aranda in May/June 2009 and R/V Skagerak in October

642008 (Fig. 1b). All cores were sliced at $0.5-2 \mathrm{~cm}$ resolution in a nitrogen- or argon-filled

65 glovebox. Dried and homogenized subsamples were analyzed by combustion for $\mathrm{C}_{\text {org }}$ after

66 decalcification, and by ICP-OES after total digestion $\left(\mathrm{HF} / \mathrm{HClO}_{4} / \mathrm{HNO}_{3}\right)$ for selected elements.

67 A parallel series of samples was taken at $1-5 \mathrm{~cm}$ resolution in a dark lab for pigment analysis.

68 Cold HPLC-grade acetone: methanol: milliQ water (80:15:5\%) was applied to dried, 
Publisher: GSA

Journal: GEOL: Geology

DOI:10.1130/G36454.1

69 homogenized subsamples, and the filtered extracts were analyzed by high performance liquid

70 chromatography (HPLC) for echinenone and zeaxanthin. Complete methodological details are

71 given in the Data Repository. All raw elemental and pigment concentration data are presented in

72 Table DR2.

\section{Core Chronologies}

LL19 has been comprehensively dated as described elsewhere (Jilbert and Slomp, 2013)

75 by ${ }^{210} \mathrm{~Pb}$ dating of the upper sediments and matching of the $\mathrm{C}_{\text {org }}$ profile of deeper sediments to

76 Loss on Ignition (LOI) in the Pb pollution-isochrone/PSV-dated master core 372740-3 from the

77 Gotland Deep (Lougheed et al., 2012). This chronology was used to determine the duration of

78 the hypoxic interval during the Holocene Thermal Maximum $\left(\mathrm{HI}_{\mathrm{HTM}}\right)$ in the Baltic Proper, and

79 the timing of its termination at $\sim 4.0 \mathrm{ka}$ (Fig. DR1). For dating of SR5, six bulk-sediment

80 radiocarbon dates were obtained from a nearby core (MSM-16/1-082-03: 61.0768 ${ }^{\circ}$,

$8120.6233^{\circ} \mathrm{E}$ ) including 5 within an interval apparently corresponding to the $\mathrm{HI}_{\mathrm{HTM}}$ (as determined

82 by elevated $\mathrm{C}_{\text {org }}$ values). Equivalent depths in MSM-16/1-082-03 and SR5 were identified by

83 matching the $\mathrm{C}_{\text {org }}$ profiles of the two cores. The duration of the $\mathrm{HI}_{\mathrm{HTM}}$ at $\mathrm{SR} 5$ was then estimated

84 by calibrating the oldest and youngest radiocarbon dates of the $\mathrm{HI}_{\mathrm{HTM}}$ to calendar ages using the

85 Marine13 calibration curve in Oxcal v4.2 (Bronk Ramsey, 2009), assuming a constant reservoir

86 age (Fig. DR1). Complete details of the dating approach are given in the Data Repository.

\section{Bathymetric Modeling}

The bathymetric modeling is based on the empirical shore-level displacement model

89 described in Påsse and Andersson (2005). These authors assumed glacio-isostatic uplift of

90 Fennoscandia over the period $20 \mathrm{ka}$-present to be represented by a composite curve of one slow

91 and one fast component, for which general mathematical expressions could be formulated. 
Publisher: GSA

Journal: GEOL: Geology

DOI:10.1130/G36454.1

92 Taking into account eustatic sea level rise, the parameters of the expressions were fitted to

93 empirical data on shore-level curves from 79 sites distributed across Scandinavia. We

94 interpolated these parameters across a 2D grid of present day elevation in the Baltic region (2 by

$951 \mathrm{~min}$ in longitude and latitude, respectively, www.io-warnemuende.de/iowtopo). Past elevation

96 at any position on the grid was calculated by subtracting uplift and eustatic sea level rise from

97 the present day value.

\section{$98 \quad$ RESULTS AND DISCUSSION}

The Baltic Sea became connected to the global ocean at around 8.5 ka (Andrén et al.,

100 2011), during the period known as the Holocene Thermal Maximum (HTM, e.g., Renssen et al.,

101 2009). Previous studies have demonstrated the subsequent occurrence of a hypoxic interval (here

102 termed $\mathrm{HI}_{\mathrm{HTM}}$ ) in the Baltic Proper, which lasted for several thousand years (Zillén et al., 2008).

103 The $\mathrm{HI}_{\mathrm{HTM}}$ has been linked to high salinity and a strongly stratified water column (Zillén et al.,

104 2008), resulting from both the drier, warmer climate of the HTM and from a deep configuration

105 of the Danish Straits, which promoted saline water inflows into the Baltic Sea (Gustafsson and

106 Westman, 2002). Our paleobathymetric modeling shows that the sills of the Aland Sea were also

107 substantially deeper from 8-4 ka than during the late Holocene (Fig. 2). This suggests that the

108 intermediate-salinity deep waters of the Baltic Proper during the $\mathrm{HI}_{\mathrm{HTM}}$ may have extended into

109 the Bothnian Sea.

110 High resolution sediment chemical records confirm that intensely hypoxic conditions

111 were present in both the Baltic Proper and the Bothnian Sea during the $\mathrm{HI}_{\mathrm{HTM}}$ (Fig. 3a). In both

112 sub-basins, the sediments of the $\mathrm{HI}_{\mathrm{HTM}}$ are characterized by high organic carbon $\left(\mathrm{C}_{\text {org }}\right)$ and

113 molybdenum (Mo) contents, high organic carbon to total phosphorus $\left(\mathrm{C}_{\text {org }} / \mathrm{P}_{\text {tot }}\right)$ ratios, and

114 enhanced concentrations of the cyanobacterial pigments echinenone and zeaxanthin (Ech./ $\mathrm{C}_{\text {org }}$ 
Publisher: GSA

Journal: GEOL: Geology

DOI:10.1130/G36454.1

115 and Zeax./ $\mathrm{C}_{\text {org }}$ ), suggesting a stratified water column in which deep water hypoxia promoted

116 sedimentary $\mathrm{P}$ regeneration and cyanobacteria blooms. The close correlation between the

117 enhanced pigment concentrations and organic carbon contents indicate that the increase in

118 organic matter in the sediment during the $\mathrm{HI}_{\mathrm{HTM}}$ is due to increased production and preservation

119 of marine organic matter. Laminated sediments characteristic of this interval have been observed

120 in multiple cores from the Baltic Proper, and at least one other core from the Bothnian Sea

121 (Zillén et al., 2008), suggesting that our records are broadly representative for these sub-basins.

122 No reliable PSV age model yet exists for the Bothnian Sea, and radiocarbon dating of Baltic Sea

123 sediments in general is hampered by reservoir age uncertainties and contamination with

124 reworked carbon (Lougheed et al., 2013). However, the radiocarbon-estimated duration of the

$125 \mathrm{HI}_{\mathrm{HTM}}$ in the Bothnian Sea $\left(\sim 3.8 \mathrm{k} . \mathrm{y}\right.$. , Fig. DR1) is similar to that of the $\mathrm{HI}_{\mathrm{HTM}}$ in the Baltic

126 Proper (3.3 k.y.), suggesting that the hypoxic intervals in the two sub-basins may have been co-

127 eval.

128 The maximum intensity of hypoxia early in the $\mathrm{HI}_{\mathrm{HTM}}$ was greater in the Bothnian Sea

129 than in the Baltic Proper. $\mathrm{C}_{\text {org }} / \mathrm{P}_{\text {tot }}$, ratios and the concentrations of cyanobacterial pigments in

130 Bothnian Sea sediments show maxima up to a factor 2-3 higher than the corresponding values in

131 the Baltic Proper (Fig. 3a). Molybdenum to $\mathrm{C}_{\text {org }}$ scatter plots for the two sub-basins also suggest

132 relatively stagnant conditions in the Bothnian Sea (Fig. 3b). The sediments of the Baltic Proper

133 show tightly-correlated $\mathrm{Mo}$ and $\mathrm{C}_{\text {org }}$ concentrations between $\sim 3.5$ and $7 \% \mathrm{C}_{\text {org }}$, due to the

134 efficient scavenging of Mo by organic matter in the presence of hydrogen sulfide and negligible

135 basin reservoir effects (Jilbert and Slomp, 2013). In contrast, Bothnian Sea sediments of $>4 \%$

$136 \mathrm{C}_{\text {org }}$ (as recorded early in the $\mathrm{HI}_{\mathrm{HTM}}$, Fig. 3a) show Mo concentrations lower than predicted by 
Publisher: GSA

Journal: GEOL: Geology

DOI:10.1130/G36454.1

137 the corresponding $\mathrm{C}_{\text {org }}$ value (Fig. 3b), suggesting partial depletion of water column Mo due to a

138 longer deep water replacement time (Algeo and Lyons, 2006).

139 The $\mathrm{HI}_{\mathrm{HTM}}$ in the Baltic Proper terminated abruptly at 4.0 ka (Jilbert and Slomp, 2013),

140 as determined by highly resolved paleomagnetic secular variation (PSV) dating (Lougheed et al.,

141 2012). In contrast, the $\mathrm{HI}_{\mathrm{HTM}}$ in the Bothnian Sea was characterized by a long-term decline in

142 intensity after an initial maximum (Fig. 3a). A combination of isostatic and climatic factors may

143 have led to the termination of the $\mathrm{HI}_{\mathrm{HTM}}$ in both sub-basins. Our paleobathymetric

144 reconstructions show a gradual shoaling of the Åland Sea sills from 8 ka to 4 ka (Fig. 2), which

145 likely caused a progressive diminishment of the deep water exchange and simultaneous decline

146 in hypoxia in the Bothnian Sea. This transition was also characterized by increasing $\mathrm{P}$ and iron

$147(\mathrm{Fe})$ concentrations in the sediments of SR5, which continued after the termination of the $\mathrm{HI}_{\mathrm{HTM}}$

148 (Fig. DR2). Although variability in mass accumulation rate at SR5 cannot be determined

149 accurately with the available data, the increasing $\mathrm{P}$ and Fe concentrations strongly suggest an

150 increase in the rate of $\mathrm{P}$ and Fe burial during this interval. Today, the Bothnian Sea acts as a sink

151 for P exported from the surface waters of the Baltic Proper (Savchuk, 2005), through widespread

152 incorporation of $\mathrm{P}$ into Fe oxyhydroxides in surface sediments, and into reduced Fe phosphates

153 below the zone of anaerobic oxidation of methane deeper in the sediments (Slomp et al., 2013).

154 We propose that the gradual severing of deep water exchange through the Aland Sea led to the

155 progressive activation of this Fe-P sink, by improving oxygenation of the Bothnian Sea and

156 allowing Fe oxyhydroxides to accumulate in the sediments.

157 The abrupt termination of the $\mathrm{HI}_{\mathrm{HTM}}$ in the Baltic Proper may have been caused by a

158 critical threshold of $\mathrm{P}$ burial rate in the Bothnian Sea being passed at $\sim 4.0 \mathrm{ka}$, or by a climatic

159 trigger acting in unison with enhanced $\mathrm{P}$ burial. Summer air temperatures during the HTM in the 
Publisher: GSA

Journal: GEOL: Geology

DOI:10.1130/G36454.1

160 Baltic region declined after $\sim 6 \mathrm{ka}$ (Renssen et al., 2009). This long-term shift to cooler

161 conditions may have been accompanied by increased precipitation in the Baltic catchment,

162 reducing stratification of the Baltic Sea (Gustafsson and Westman, 2002) and favoring the

163 termination of hypoxia.

Hypoxic conditions reappeared in the Baltic Proper during the Medieval Climate

165 Anomaly $\left(\mathrm{HI}_{\mathrm{MCA}}\right.$ ), and in the late $20^{\text {th }}$ century (Fig. 3a). The absence of such conditions in the

166 Bothnian Sea shows that reduced deep-water exchange through the Åland Sea limited the spatial

167 extent of hypoxia during these intervals. Furthermore, hypoxia in the Baltic Proper occurred

168 despite the active export of $\mathrm{P}$ into Bothnian Sea sediments. The rate of $\mathrm{P}$ burial in the Bothnian

169 Sea in recent decades has been estimated at 10-20 kton/yr (Wulff et al., 2001; Savchuk, 2005).

170 During the same interval, the rate of external P input to the Baltic Sea as a whole has varied from

$171 \sim 40-70$ kton/yr, much of which has entered the Baltic Proper directly (Gustafsson et al., 2012).

172 Along with internal P regeneration, these high loads have maintained modern hypoxia despite the

173 substantial export of $\mathrm{P}$ to the Bothnian Sea. Assuming regeneration and burial rates of $\mathrm{P}$ in the

174 Baltic Proper to be similar during all hypoxic intervals (Jilbert and Slomp, 2013), this suggests

175 that the $\mathrm{HI}_{\mathrm{MCA}}$ was also partly driven by external $\mathrm{P}$ inputs, which more than compensated for $\mathrm{P}$ 176 burial in the Bothnian Sea.

177 Glacio-isostatic rebound likely influenced the distribution of hypoxia in many high-

178 latitude shelf basins during the Holocene. Our evidence from the Baltic Sea suggests hypoxia is

179 favored when connection to the open ocean is restricted, but still sufficient to allow the

180 development of a stratified water column, and when P sinks are limited in extent. A large body

181 of evidence supports the influence of glacio-isostasy on hypoxia in similar environments. The

182 initial marine incursion into Hudson Bay at $\sim 8 \mathrm{ka}$ was characterized by high-salinity deep 
Publisher: GSA

Journal: GEOL: Geology

DOI:10.1130/G36454.1

183 waters, a stratified water column and low-oxygen conditions (Bilodeau et al., 1990), suggesting

184 an analogous scenario to the $\mathrm{HI}_{\mathrm{HTM}}$ in the Baltic. The subsequent freshening and mixing of

185 Hudson Bay may be partly explained by bathymetric changes due to glacio-isostatic rebound. In

186 contrast, severe euxinia has developed in Norwegian fjords as their seaward sills have shoaled

187 throughout the Holocene (Skei, 1988). Shoaling of the glacially-incised Lower St. Lawrence

188 Estuary (Duchesne et al., 2010) likely also preconditioned the modern vulnerability of this

189 system to stratification and hypoxia (Lefort et al., 2012).

Theoretically, complete glacio-isostatic isolation of shelf basins should lead to their

191 freshening and mixing, as occurred during the closure of the Champlain Sea (Cronin et al.,

192 2008). However, in fjord environments with an annual sea-ice cycle, hypersaline deep waters

193 may form as a result of salt 'freeze-out' during ice growth. Glacio-isostatic rebound of such

194 coastlines in Antarctica has been shown to create permanently stratified, hypoxic lakes after

195 isolation from the ocean (Gallagher et al., 1989). Hence, the timeline of the response of hypoxia

196 to glacio-isostatic change may vary strongly between different shelf basin environments.

\section{ACKNOWLEDGMENTS}

198 We thank the captain, crew and scientific participants aboard R/V Aranda (2009) for

199 their assistance with the fieldwork. Ton Zalm, Arnold van Dijk and Helen de Waard are

200 acknowledged for analytical assistance in Utrecht. Erik Smedberg is thanked for graphical

201 work related to Fig. 1. Bryan Lougheed is thanked for discussions relating to dating of Baltic

202 Sea sediments. Nina Reuss is thanked for assistance with pigment analysis. This research was

203 funded by a Netherlands Organisation for Scientific Research (NWO) Vidi grant and a

204 European Research Council (ERC) Starting Grant (278364) awarded to C.P.S., a Wallenberg 
Publisher: GSA

Journal: GEOL: Geology

DOI:10.1130/G36454.1

Scholar grant to D.J.C., Baltic Sea 2020 and the EU-BONUS projects HYPER and Baltic

Gas.

207

208

209

210

211

212

213

214

215

216

217

218

219

220

221

222

223

224

225

226

\section{REFERENCES CITED}

Algeo, T.J., and Lyons, T.W., 2006, Mo-total organic carbon covariation in modern anoxic marine environments: Implications for analysis of paleoredox and paleohydrographic conditions: Paleoceanography, v. 21, no. 1, doi:10.1029/2004PA001112.

Amantov, A., Fjeldskaar, W., and Cathles, L., 2011, Glacial Erosion/Sedimentation of the Baltic Region and the Effect on the Postglacial Uplift, in Harff, J., Bjorck, S., and Hoth, P., eds., Baltic Sea Basin: Berlin, Springer-Verlag, p. 53-71.

Andrén, T., Bjorck, S., Andren, E., Conley, D., Zillén, L., and Anjar, J., 2011, The Development of the Baltic Sea Basin During the Last 130 ka, in Harff, J., Bjorck, S., and Hoth, P., eds., Baltic Sea Basin: Berlin, Springer-Verlag, p. 75-97.

Bilodeau, G., Devernal, A., Hillairemarcel, C., and Josenhans, H., 1990, Postglacial paleoceanography of Hudson Bay- stratigraphic, microfaunal, and palynological evidence: Canadian Journal of Earth Sciences, v. 27, no. 7, p. 946-963, doi:10.1139/e90-098.

Bronk Ramsey, C.B., 2009, Bayesian Analysis of Radiocarbon Dates: Radiocarbon, v. 51, no. 1, p. $337-360$.

Cronin, T.M., Manley, P.L., Brachfeld, S., Manley, T.O., Willard, D.A., Guilbault, J.P., Rayburn, J.A., Thunell, R., and Berke, M., 2008, Impacts of post-glacial lake drainage events and revised chronology of the Champlain Sea episode 13-9 ka: Palaeogeography, Palaeoclimatology, Palaeoecology, v. 262, no. 1-2, p. 46-60, doi:10.1016/j.palaeo.2008.02.001. 
Publisher: GSA

Journal: GEOL: Geology

DOI:10.1130/G36454.1

227 Diaz, R.J., and Rosenberg, R., 2008, Spreading dead zones and consequences for marine

228 ecosystems: Science, v. 321, no. 5891, p. 926-929, doi:10.1126/science.1156401.

229 Duchesne, M.J., Pinet, N., Bedard, K., St-Onge, G., Lajeunesse, P., Campbell, D.C., and Bolduc,

230 A., 2010, Role of the bedrock topography in the Quaternary filling of a giant estuarine basin:

231 The Lower St. Lawrence Estuary, Eastern Canada: Basin Research, v. 22, no. 6, p. 933-951.

232 Ehlers, J., Gibbard, P.L., and Hughes, P.D., eds., 2011, Quaternary Glaciations - Extent and

233 Chronology: A Closer Look: Amsterdam, Elsevier, Developments in Quaternary Science

234 Series, v. 15, 1108 p.

235 Farmer, D.F.H., and Freeland, H.J., 1983, The physical oceanography of fjords: Progress in

236 Oceanography, v. 12, no. 2, p. 147-219, doi:10.1016/0079-6611(83)90004-6.

237 Gallagher, J.B., Burton, H.R., and Calf, G.E., 1989, Meromixis in an Antarctic fjord - A

238 precursor to meromictic lakes on an isostatically rising coastline: Hydrobiologia, v. 172,

239 p. 235-254, doi:10.1007/BF00031625.

240 Gustafsson, B.G., and Westman, P., 2002, On the causes for salinity variations in the Baltic Sea

241 during the last 8500 years: Paleoceanography, v. 17, no. 3, doi:10.1029/2000PA000572.

242 Gustafsson, B.G., Schenk, F., Blenckner, T., Eilola, K., Meier, H.E.M., Mueller-Karulis, B.,

243 Neumann, T., Ruoho-Airola, T., Savchuk, O.P., and Zorita, E., 2012, Reconstructing the

244 development of Baltic Sea eutrophication 1850-2006: Ambio, v. 41, p. 534-548,

245 doi:10.1007/s13280-012-0318-x.

246 Jarvis, I., Lignum, J.S., Groecke, D.R., Jenkyns, H.C., and Pearce, M.A., 2011, Black shale

247 deposition, atmospheric CO2 drawdown, and cooling during the Cenomanian-Turonian

248 Oceanic Anoxic Event: Paleoceanography, v. 26, doi:10.1029/2010PA002081. 
Publisher: GSA

Journal: GEOL: Geology

DOI:10.1130/G36454.1

249

250

251

252

253

254

255

256

257

258

259

260

261

262

263

264

265

266

267

268

269

270

271

Jilbert, T., and Slomp, C.P., 2013, Rapid high-amplitude variability in Baltic Sea hypoxia during the Holocene: Geology, v. 41, p. 1183-1186, doi:10.1130/G34804.1.

Kessler, M.A., Anderson, R.S., and Briner, J.P., 2008, Fjord insertion into continental margins driven by topographic steering of ice: Nature Geoscience, v. 1, no. 6, p. 365-369, doi:10.1038/ngeo201.

Lefort, S., Gratton, Y., Mucci, A., Dadou, I., and Gilbert, D., 2012, Hypoxia in the Lower St. Lawrence Estuary: How physics controls spatial patterns: Journal of Geophysical Research, Oceans, v. 117, doi:10.1029/2011JC007751.

Lougheed, B.C., Snowball, I., Moros, M., Kabel, K., Muscheler, R., Virtasalo, J.J., and Wacker, L., 2012, Using an independent geochronology based on palaeomagnetic secular variation (PSV) and atmospheric $\mathrm{Pb}$ deposition to date Baltic Sea sediments and infer C-14 reservoir age: Quaternary Science Reviews, v. 42, p. 43-58, doi:10.1016/j.quascirev.2012.03.013.

Lougheed, B.C., Filipsson, H.L., and Snowball, I., 2013, Large spatial variations in coastal C-14 reservoir age: A case study from the Baltic Sea: Climate of the Past, v. 9, p. 1015-1028, doi:10.5194/cp-9-1015-2013.

Lundberg, C., Jakobsson, B.M., and Bonsdorff, E., 2009, The spreading of eutrophication in the eastern coast of the Gulf of Bothnia, northern Baltic Sea - An analysis in time and space: Estuarine, Coastal and Shelf Science, v. 82, p. 152-160, doi:10.1016/j.ecss.2009.01.005.

Nota, D.J.G., and Loring, D.H., 1964, Recent depositional conditions in the St. Lawrence River and Gulf - A reconnaissance survey: Marine Geology, v. 2, no. 3, p. 198-235, doi:10.1016/0025-3227(64)90040-4.

Påsse, T., and Andersson, L., 2005, Shore-level displacement in Fennoscandia calculated from empirical data: GFF, v. 127, p. 253-268, doi:10.1080/11035890501274253. 
Publisher: GSA

Journal: GEOL: Geology

DOI:10.1130/G36454.1

272 Renssen, H., Seppä, H., Heiri, O., Roche, D.M., Goosse, H., and Fichefet, T., 2009, The spatial

273 and temporal complexity of the Holocene thermal maximum: Nature Geoscience, v. 2, p.

274 411-414, doi: 10.1038/NGEO513.

275 Savchuk, O.P., 2005, Resolving the Baltic Sea into seven subbasins: N and P budgets for 1991-

276 1999: Journal of Marine Systems, v. 56, no. 1-2, p. 1-15,

277 doi:10.1016/j.jmarsys.2004.08.005.

278 Skei, J.M., 1988, Framvaren - Environmental setting: Marine Chemistry, v. 23, no. 3-4, p. 209-

279 218, doi:10.1016/0304-4203(88)90093-X.

280 Slomp, C.P., Mort, H.P., Jilbert, T., Reed, D.C., Gustafsson, B.G., and Wolthers, M., 2013,

281 Coupled dynamics of iron and phosphorus in sediments of an oligotrophic coastal basin and

282 the impact of anaerobic oxidation of methane: PLoS ONE, v. 8, no. 4, p. e62386,

283 doi:10.1371/journal.pone.0062386.

284 Wulff, F., Rahm, L., Hallin, A.-K., and Sanberg, S., 2001, A nutrient budget model of the Baltic

285 Sea, in Wulff, F., Rahm, L., and Larsson, P., eds., A systems analysis of the Baltic Sea:

286 Berlin, Springer-Verlag, p. 353-372.

287 Zillén, L., Conley, D.J., Andren, T., Andren, E., and Bjorck, S., 2008, Past occurrences of

288 hypoxia in the Baltic Sea and the role of climate variability, environmental change and

289 human impact: Earth-Science Reviews, v. 91, no. 1-4, p. 77-92,

290 doi:10.1016/j.earscirev.2008.10.001.

\section{FIGURE CAPTIONS}

292 Figure 1. Geography and hydrography of the Baltic Sea. A: Major glacially-incised shelf basins

293 in the high northern latitudes. White dashed line = approximate extent of Laurentide and

294 Scandinavian ice sheets at the Last Glacial Maximum (Ehlers et al., 2011). Red solid lines = 
Publisher: GSA

Journal: GEOL: Geology

DOI:10.1130/G36454.1

295 major fjord coastlines. Green $=$ major flooded shelf basins with localized deeps and restricted

296 connection to the open ocean. B: Bathymetric map of the Baltic Sea, showing the sub-basins

297 relevant to this study (latitude and longitude in degrees $\mathrm{N}$ and E). Red dashed line indicates

298 transect shown in B. B: Salinity and oxygen concentrations along the transect. Left to Right $=$

299 South to North. BP = Baltic Proper, BS = Bothnian Sea, ÅS = Åland Sea. Black dashed line

300 highlights the sills of the Åland Sea. Oxygen and salinity data was obtained from the Baltic

301 Environmental Database. Negative oxygen indicates hydrogen sulfide.

302 Figure 2. Isostatic control on the geometry of the Åland Sea sills during the Holocene. A:

303 temporal evolution (vertical axis) of water depth (shading) on a transect across the northern sill

304 of the Åland Sea (horizontal axis). B: Elevation maps of the Åland Sea region at 1000 yr B.P.

305 and $6000 \mathrm{yr}$ B.P. The position of the transect in A is shown in red. Both plots are generated by

306 interpolation of regional shoreline displacement curves from Påsse and Andersson (2005).

307 Figure 3. Sediment records from the Bothnian Sea (SR5) and Baltic Proper (LL19). A:

308 Composite geochemical records from multi-core and gravity core samples. Hypoxic intervals,

309 determined by enrichments in $\mathrm{C}_{\text {org }}$ and other parameters, are highlighted by horizontal gray bars.

$310 \mathrm{HI}_{\mathrm{HTM}}=$ Hypoxic Interval during the Holocene Thermal Maximum; $\mathrm{HI}_{\mathrm{MCA}}=$ Hypoxic Interval

311 during the Medieval Climate Anomaly; $\mathrm{HI}_{\mathrm{Mod} .}=$ Modern hypoxic interval. The depth

312 corresponding to $4.0 \mathrm{ka}$ is indicated in each core. Zeax. = zeaxanthin; Ech. = echinenone.

313 Pigment concentrations are reported as $\mu$ mol pigment per gram $\mathrm{C}_{\text {org. }}$. B: Molybdenum (Mo)

314 versus organic carbon $\left(\mathrm{C}_{\mathrm{org}}\right)$ crossplots of the gravity core data. Multi-core data are excluded due

315 to the distorting influence of fresh organic matter in recently deposited sediments. Trendline in

316 LL19 represents the linear regression for $3.5<\mathrm{C}_{\text {org }}(\%)<7$, and is typical for weakly restricted,

317 weakly euxinic basins. Gray field left of LL19 trendline $\left(\mathrm{C}_{\mathrm{org}}<\sim 3.5 \%\right)$ indicates sediments 
Publisher: GSA

Journal: GEOL: Geology

DOI:10.1130/G36454.1

318 deposited in non-euxinic conditions with minimal Mo enrichment. Trendline in SR5 represents

319 the equivalent gradient to LL19, displaced left to account for an apparent lower threshold $\mathrm{C}_{\text {org }}$

320 value $(\sim 1 \%)$ for molybdenum enrichment at this site. Gray fields right of each trendline indicate

321 sediments deposited under a water column depleted with respect to dissolved Mo, hence

322 experiencing basin reservoir effects (Algeo and Lyons, 2006).

$323{ }^{1}$ GSA Data Repository item 2015xxx, including complete methods, Figures DR1 and DR2 and

324 Tables DR1 and DR2, is available online at www.geosociety.org/pubs/ft2015.htm, or on request

325 from editing@geosociety.org or Documents Secretary, GSA, P.O. Box 9140, Boulder, CO

326 80301, USA. 
Click here to download Figure: Combined figures $07.022015 \mathrm{pdf}$
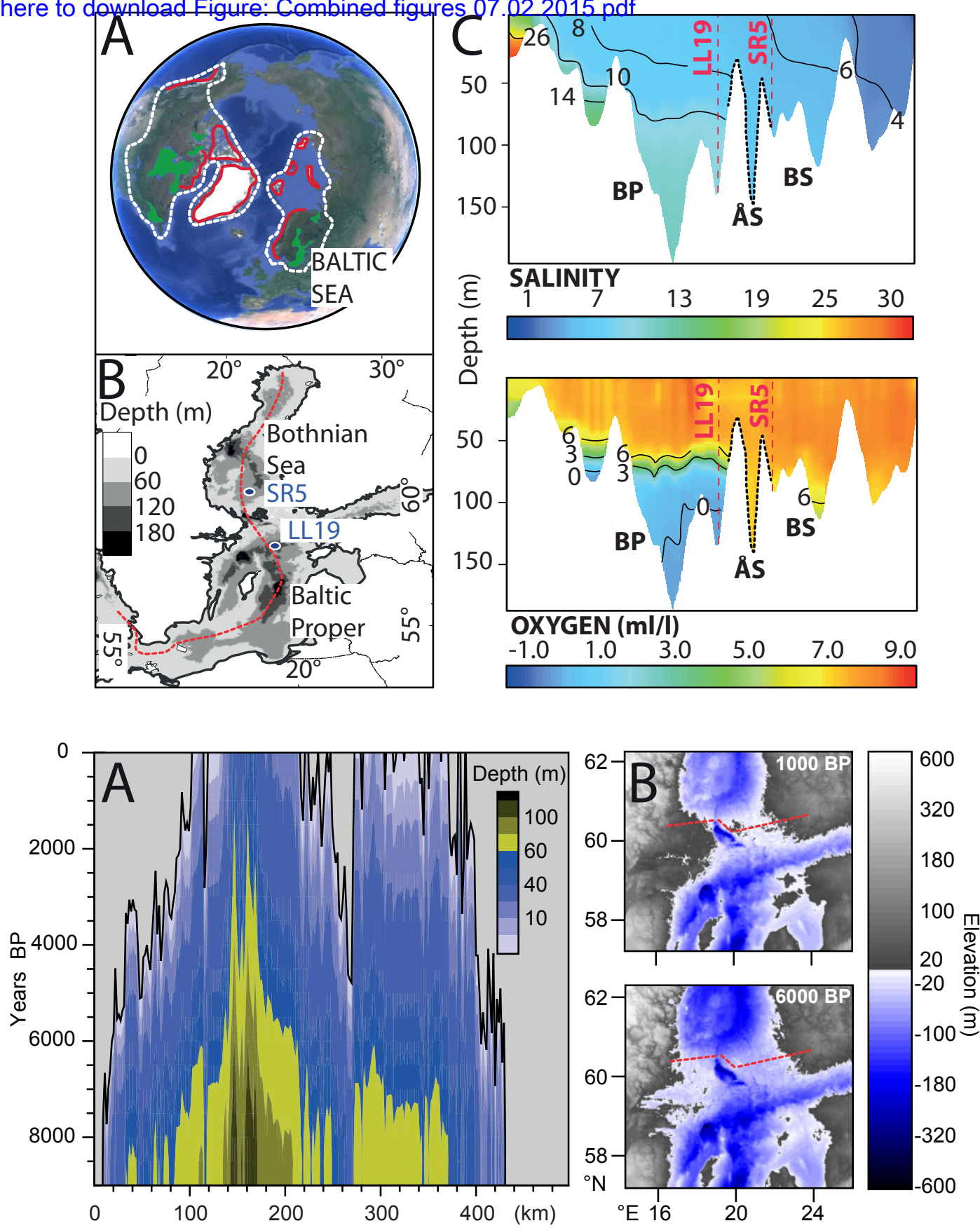

Figure 1

Figure 2

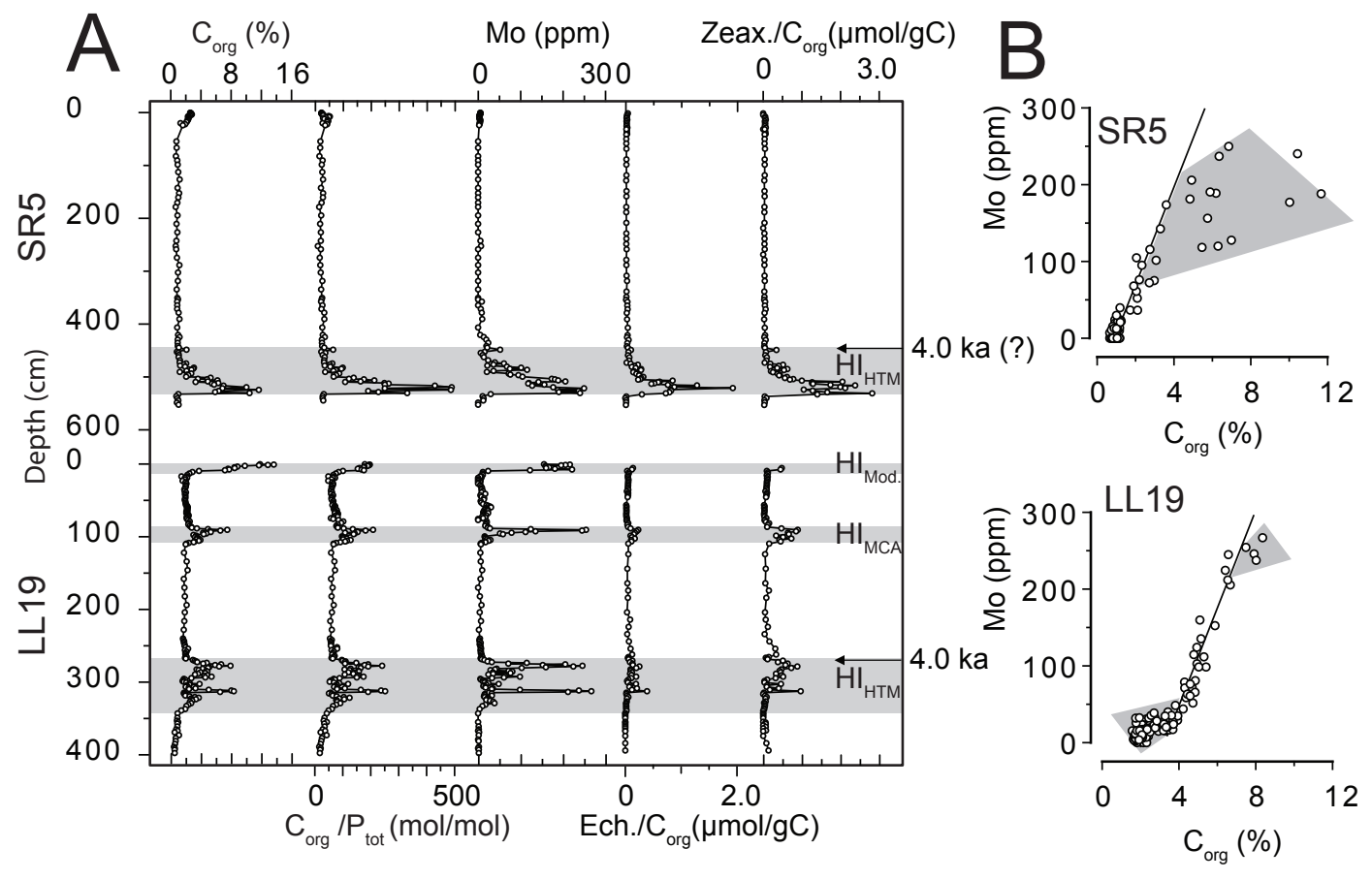

Figure 3 


\section{Data Repository Item for "Glacio-isostatic control on hypoxia}

2 in a high-latitude shelf basin"

3 Tom Jilbert* ${ }^{1}$, Daniel J. Conley ${ }^{2}$, Bo G. Gustafsson ${ }^{3}$, Carolina P. Funkey ${ }^{2}$, Caroline P.

$4 \quad$ Slomp $^{1}$

$5{ }^{1}$ Department of Earth Sciences (Geochemistry), Faculty of Geosciences, Utrecht University

6 P.O. Box 80.021, 3508 TA Utrecht, The Netherlands

$7 \quad{ }^{2}$ Department of Geology, Lund University, Sölvegatan 12, S-223 62 Lund, Sweden

$8{ }^{3}$ Baltic Nest Institute, Baltic Sea Centre, Stockholm University, S-106 91 Stockholm, Sweden

$9 \quad *$ Corresponding author, now at: Department of Environmental Sciences, P.O. Box 65, 00014

10 University of Helsinki, Helsinki, Finland, tom.jilbert@helsinki.fi, Tel: +358919157923 


\section{COMPLETE METHODS}

\section{Sediment coring, sampling and chemical analysis}

Sediment multi-cores and gravity cores were collected from sites LL19 in the Baltic Proper $\left(58.8807^{\circ} \mathrm{N}, 20.3108^{\circ} \mathrm{E}, 169 \mathrm{~m}\right.$ water depth $)$ and SR5 in the Bothnian Sea $\left(61.0833^{\circ} \mathrm{N}\right.$, $19.5797^{\circ} \mathrm{E}, 126 \mathrm{~m}$ water depth) during cruises with R/V Aranda in May/June 2009 and R/V Skagerak in October 2008 (Fig. 1 of main article). All cores were sliced at $0.5-2 \mathrm{~cm}$ resolution in a nitrogen- or argon-filled glovebox. Sediment samples were freeze-dried and returned to the glovebox to be powdered and ground in an agate mortar. Subsamples were decalcified by shaking in excess $1 \mathrm{M} \mathrm{HCl}$, initially for $12 \mathrm{~h}$ and for a further $4 \mathrm{~h}$ after addition of new acid. The decalcified sediment was dried, ground in an agate mortar and analyzed by combustion for $\mathrm{C}_{\text {org }}$ by Fisons NA 1500 NCS (precision and accuracy $<2 \%$ based on an atropine/acetanilide standard calibration and checked against internal laboratory standard sediments). A second subsample was dissolved in $2.5 \mathrm{ml} \mathrm{HF} \mathrm{(40 \% )} \mathrm{and} 2.5 \mathrm{ml}$ of an $\mathrm{HClO}_{4} / \mathrm{HNO}_{3}$ mixture, in a closed Teflon bomb at $90{ }^{\circ} \mathrm{C}$ for $12 \mathrm{~h}$. The acids were then evaporated at $190{ }^{\circ} \mathrm{C}$ and the resulting gel was dissolved in $1 \mathrm{M} \mathrm{HNO}_{3}$, and analyzed for $\mathrm{Mo}$ (202.030 nm), P (177.495nm), and Al (308.215 nm) among other elements by ICP-OES (Ametek Spectro Arcos, precision and accuracy $<5 \%$, based on calibration to standard solutions and checked against internal laboratory standard sediments). A parallel series of samples was taken at $1-5 \mathrm{~cm}$ resolution in a dark lab in preparation for pigment analysis. These samples were freeze-dried and ground, then mixed with cold HPLC-grade acetone: methanol: milliQ water $(80: 15: 5 \%)$, sonicated and stored in a freezer $\left(-20^{\circ} \mathrm{C}\right)$ overnight. Extracts were centrifuged and filtered at $0.45 \mu \mathrm{m}$, and analyzed by high performance liquid chromatography (HPLC) on a Shimadzu Prominence HPLC equipped with an on-line photodiode array detector (SPD-M20A PDA) and an auto-sampler (Sil-10AF). See Funkey et 
al. (2014) for more details. All raw elemental and pigment concentration data are presented in Table DR2.

\section{Core chronologies}

Multi-core and gravity core data were combined on the basis of overlaps in the geochemical profiles. LL19 has been comprehensively dated as described elsewhere (Jilbert and Slomp, 2013) by ${ }^{210} \mathrm{~Pb}$ dating of the upper sediments and matching of the $\mathrm{C}_{\text {org }}$ profile of deeper sediments to Loss on Ignition (LOI) in the $\mathrm{Pb}$ pollution-isochrone/PSV-dated master core 372740-3 from the Gotland Deep (Lougheed et al., 2012a). This chronology was used to determine the duration of the hypoxic interval during the Holocene Thermal Maximum $\left(\mathrm{HI}_{\mathrm{HTM}}\right)$ in the Baltic Proper, and the timing of its termination at $4.0 \mathrm{ka}$ (Fig. DR1). PSV dating is unavailable for SR5, and accurate radiocarbon dating of Baltic Sea sediments in general is hampered by reservoir age uncertainties and the potential for contamination with reworked carbon (Lougheed et al., 2012b). Therefore we focused on estimating the duration of the $\mathrm{HI}_{\mathrm{HTM}}$ in the Bothnian Sea to assess the possibility of co-eval deposition with the $\mathrm{HI}_{\mathrm{HTM}}$ in the Baltic Proper. Six bulk-sediment radiocarbon dates were obtained from core MSM$16 / 1-082-03\left(61.0768^{\circ} \mathrm{N}, 20.6233^{\circ} \mathrm{E}\right)$ including 5 within the $\mathrm{HI}_{\mathrm{HTM}}$ as determined by elevated $\mathrm{C}_{\text {org }}$ values. ${ }^{14} \mathrm{C}$ determinations were carried out at the Lund University Accelerator Mass Spectrometry (AMS) laboratory. MSM-16/1-082-03 is located very close to SR5 and shows a comparable $\mathrm{C}_{\text {org }}$ profile. Equivalent depths in MSM-16/1-082-03 and SR5 were thus identified by matching the $\mathrm{C}_{\text {org }}$ profiles of the two cores. The duration of the $\mathrm{HI}_{\mathrm{HTM}}$ in SR5 was then estimated by calibrating the oldest and youngest radiocarbon dates of the $\mathrm{HI}_{\mathrm{HTM}}$ to calendar ages using the Marine13 calibration curve in Oxcal v4.2 (Bronk Ramsey, 2009) (Fig. DR1). This calculation was performed assuming a reservoir age offset $(\Delta R)$ of 0 years and applying no correction for reworked carbon. Hence, the derived ages are expected to be older than the true ages of the sediments, potentially by $>1000$ years (Lougheed et al., 2012b). If 
$\Delta \mathrm{R}$ and the contribution of reworked carbon are assumed constant, the duration of the $\mathrm{HI}_{\mathrm{HTM}}$ in the Bothnian Sea is estimated at $\sim 3.8$ k.y., which is in the same range as the $3.3 \mathrm{k} . \mathrm{y}$. duration estimated for the $\mathrm{HI}_{\mathrm{HTM}}$ in the Baltic Proper (Fig. DR1).

\section{Bathymetric modelling}

The bathymetric modelling is based on the empirical shore-level displacement model described in Påsse and Andersson (2005). These authors assumed isostatic uplift of Fennoscandia over the period 20 ka-present to be represented by a composite curve of one slow and one fast component, for which general mathematical expressions could be formulated. Taking into account eustatic sea level rise, the parameters of the expressions were fitted to empirical data on shore-level curves from 79 sites distributed across Scandinavia. We interpolated these parameters across a 2D grid of present day elevation in the Baltic region (2 by 1 minute in longitude and latitude, respectively, www.io-warnemuende.de/iowtopo). Past elevation at any position on the grid was calculated by subtracting uplift and eustatic sea level rise from the present day value. This simple means of calculation neglects possible bathymetric changes due to sediment accumulation and erosion. However, this is only relevant for deep basins areas, where accumulation is substantial, and not to the inter-basin sill areas, which are dominated by bedrock.

(1)

(1)

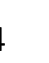

95

96

\section{7} . 

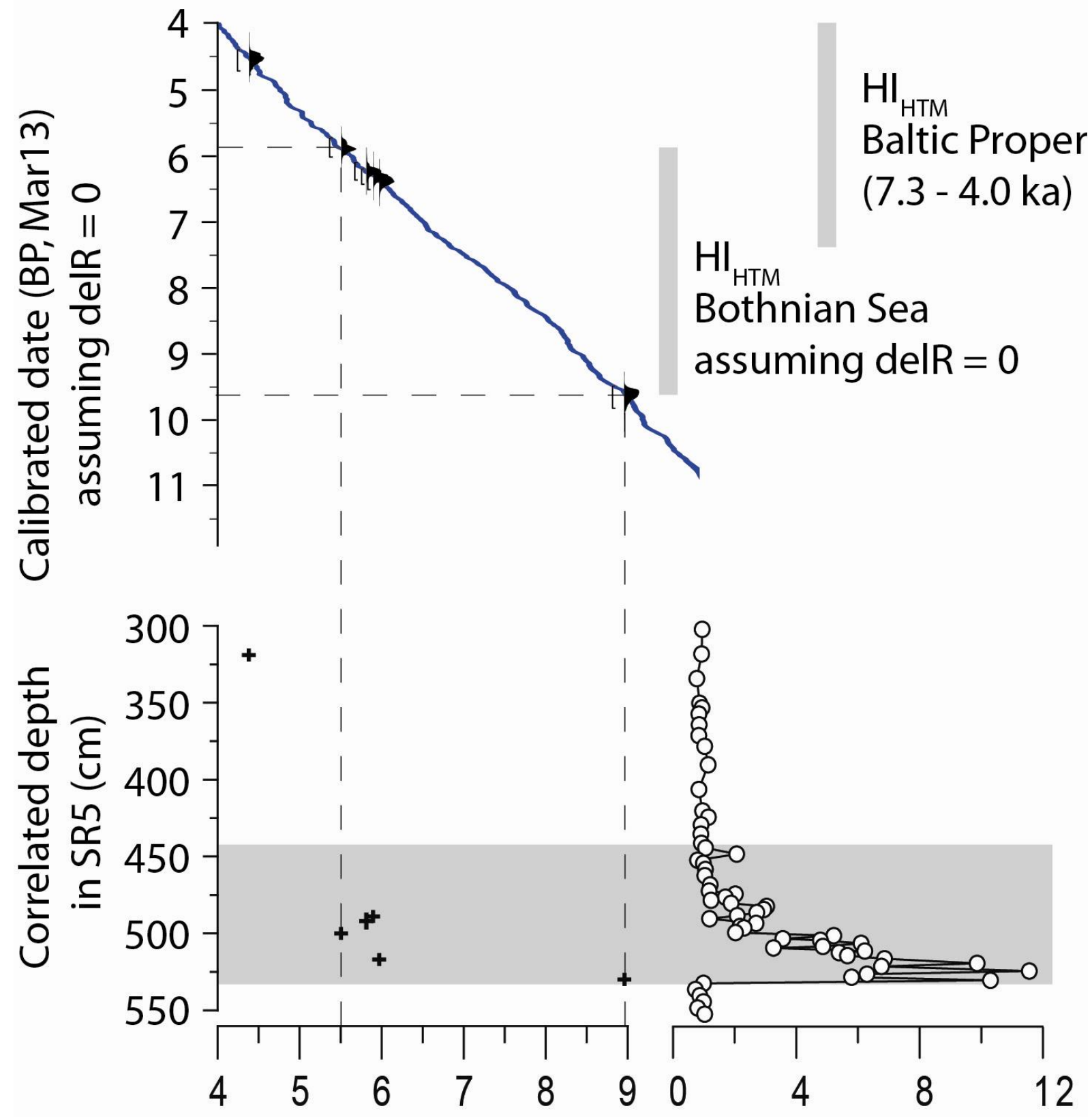

Radiocarbon

determination in

$\mathrm{C}_{\text {org }}(\%)$ 
Figure DR1. Radiocarbon dating of Bothnian Sea sediments. Six bulk radiocarbon ages were determined in samples from core MSM-16/1-082-03. The equivalent depths of the six points in SR5 were determined by correlation of the $\mathrm{C}_{\text {org }}$ profiles of the two cores. Five of the points fall within the boundaries of the $\mathrm{C}_{\text {org }}$ excursion corresponding to the $\mathrm{HI}_{\mathrm{HTM}}$ (indicated by the horizontal gray bar, $440-530 \mathrm{~cm}$ ). Vertical dashed lines indicate the maximum radiocarbon age range of points within the $\mathrm{HI}_{\mathrm{HTM}}$. Calibration of this range to Marine13 (upper plot, assuming reservoir age offset $(\Delta R)=0$ and applying no correction for reworked carbon) yields a duration of the $\mathrm{HI}_{\mathrm{HTM}}$ of $\sim 3.8 \mathrm{k}$.y. The age and duration of the $\mathrm{HI}_{\mathrm{HTM}}$ in the Baltic Proper (3.3 k.y. from 7.3 - 4.0 ka; Jilbert and Slomp, 2013) is shown for comparison. The $\mathrm{HI}_{\mathrm{HTM}}$ in the Baltic Proper is dated by Paleomagnetic Secular Variation (PSV) and has an absolute age uncertainty of $<0.5$ k.y.

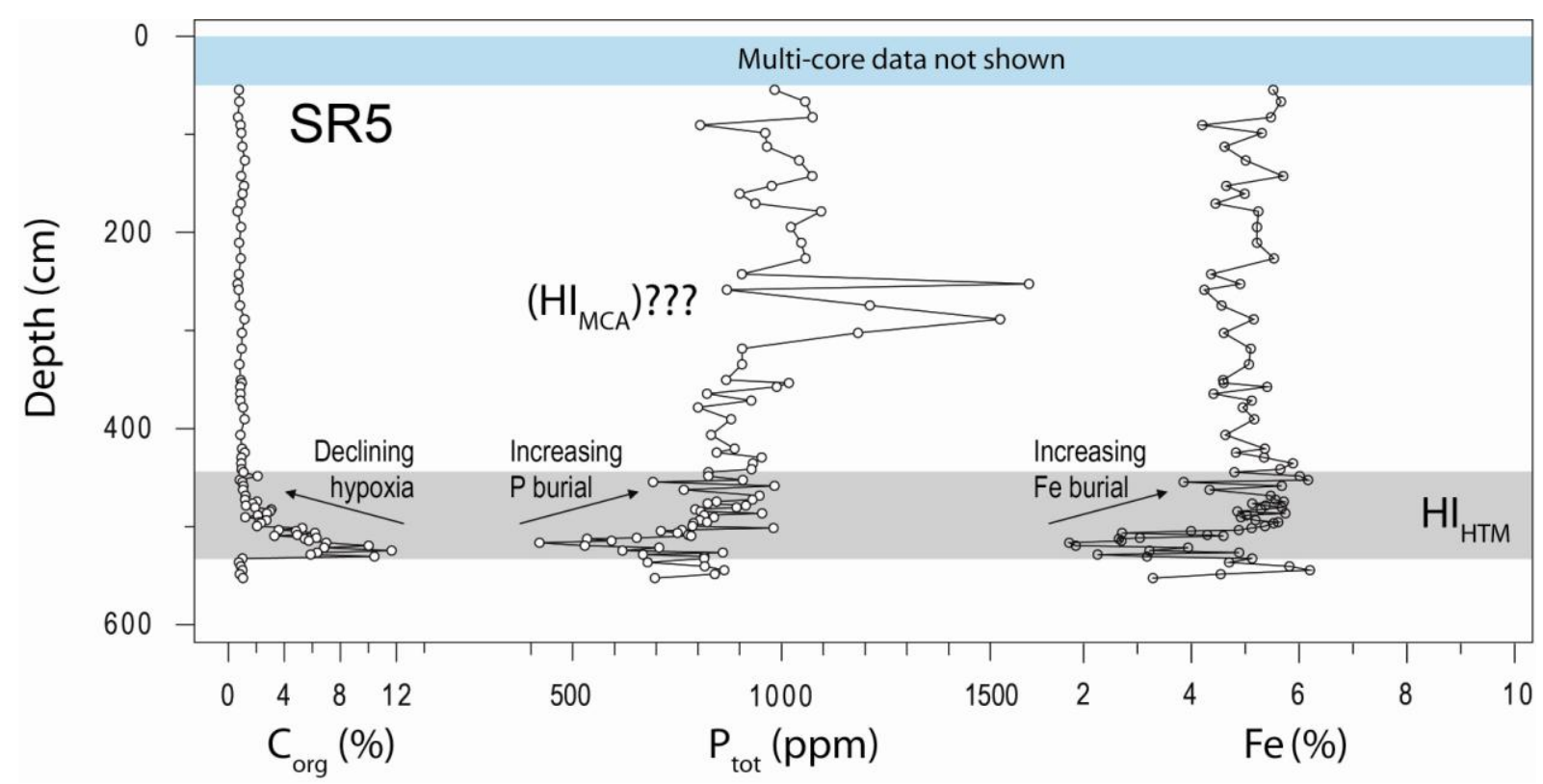

Figure DR2. $\mathbf{C}_{\text {org }}, \mathbf{P}$ and Fe concentrations at SR5. The hypoxic interval during the Holocene Thermal Maximum $\left(\mathrm{HI}_{\mathrm{HTM}}\right)$ is indicated by the horizontal gray bar. Multi-core data are not shown, in order to expand the scale on the $\mathrm{P}$ axis to highlight changes in the gravity core profile (extreme $\mathrm{P}$ concentrations in the surface sediments are related to modern-day cycling of $\mathrm{P}$ and are not representative for $\mathrm{P}$ concentrations upon burial). 


\section{SUPPLEMENTARY DISCUSSION}

125

126

127

\section{Changes in $\mathbf{P}$ burial rate in the Bothnian Sea}

Assuming the termination of the $\mathrm{HI}_{\mathrm{HTM}}$ (as determined by enhanced $\mathrm{C}_{\text {org }}$ values) at $\mathrm{SR} 5$ to occur at $4.0 \mathrm{ka}$, and the total duration of the $\mathrm{HI}_{\mathrm{HTM}}$ at SR5 to be $3.8 \mathrm{k.y}$. (Fig. DR1), we calculated mean $\mathrm{P}$ burial rates for the $\mathrm{HI}_{\mathrm{HTM}}$ and post-HI $\mathrm{HTM}_{\mathrm{HTM}}$ (i.e. 4.0 - present) intervals (Table DR1). These indicate a seven-fold higher mean $\mathrm{P}$ burial rate in the post-HI $\mathrm{HTM}_{\mathrm{HTM}}$ interval, the majority of the increase being caused by higher mass accumulation rates. However, mean P concentrations are also higher during the post-HI $\mathrm{HTM}_{\text {interval }}$ (Table DR1; Fig, DR2), suggesting a higher efficiency of $\mathrm{P}$ retention in Bothnian Sea sediments after the $\mathrm{HI}_{\mathrm{HTM}}$.

In the absence of high-resolution mass accumulation rate estimates it is difficult to accurately reconstruct $\mathrm{P}$ burial rates on shorter timescales. However, the depth profile of $\mathrm{P}$ concentration suggests that major changes in P burial may have occurred at SR5, both during and after the $\mathrm{HI}_{\mathrm{HTM}}$. The early part of the $\mathrm{HI}_{\mathrm{HTM}}$ at SR5 is characterized by the lowest $\mathrm{P}$ content of the entire record (Fig. DR2), leading to an extremely high $\mathrm{C}_{\text {org }} / \mathrm{P}_{\text {tot }}$ ratio (Fig. 3 of main article), indicative of efficient regeneration of $\mathrm{P}$ from the sediments under strongly reducing conditions. Hereafter, P concentrations first rise steeply, and then more steadily across the termination of the $\mathrm{HI}_{\mathrm{HTM}}$ (Fig. DR2). The increase mirrors the decline in $\mathrm{C}_{\text {org }}$ concentration, and suggests that the $\mathrm{P}$ burial rate increased as hypoxia became less intense due to shoaling of the deep water exchange. Furthermore, a parallel increase in the Fe concentration (Fig. DR2) suggests that this excess $\mathrm{P}$ was buried primarily in association with $\mathrm{Fe}$, either as $\mathrm{Fe}$ oxyhydroxide-bound P or vivianite, as observed in the Bothnian Sea today (Slomp et al., 2013). 
148 Interestingly, strongly elevated $\mathrm{P}$ concentrations are observed at 250-350 cm depth in SR5

149 (Fig. DR2). We speculate that this interval may be co-eval with the $\mathrm{HI}_{\mathrm{MCA}}$ in the Baltic

150 Proper, and that the high $\mathrm{P}$ concentrations result from enhanced export of surface-water $\mathrm{P}$

151 across the straits of the Åland Sea, analagous to the situation during the modern hypoxic event

152 (Savchuk, 2005). However, there is no way to confirm this theory until improved dating is

153 available for the post-HI $\mathrm{HTM}_{\mathrm{H}}$ interval at SR5.

154

155

156

157

158

159

160

161

162

SUPPLEMENTARY DATA TABLES

163

Table DR1. Calculation of $P$ burial rates at SR5. The depth and duration of the $\mathrm{HI}_{\mathrm{HTM}}$

are estimated as described in Fig. DR1.

165

\begin{tabular}{|c|c|c|c|c|c|c|c|}
\hline Period & $\begin{array}{c}\text { Depth } \\
\text { interval } \\
(\mathrm{cm})\end{array}$ & $\begin{array}{l}\text { Estimated } \\
\text { duration } \\
(\mathbf{y r})\end{array}$ & $\begin{array}{c}\text { Mean } \\
\text { sedimentation } \\
\text { rate }(\mathrm{cm} / \mathbf{y r})\end{array}$ & $\begin{array}{c}\text { Mean dry } \\
\text { bulk } \\
\text { density } \\
\left(\mathrm{g} / \mathrm{cm}^{3}\right)\end{array}$ & $\begin{array}{c}\text { Mean mass } \\
\text { accumulation } \\
\text { rate }\left(\mathrm{g} / \mathrm{cm}^{2} / \mathbf{y r}\right)\end{array}$ & $\begin{array}{c}\text { Mean } \\
\mathbf{P}_{\text {tot }} \\
\text { content } \\
\text { (ppm) }\end{array}$ & $\begin{array}{c}\text { Mean } P_{\text {tot }} \\
\text { accumulation } \\
\text { rate }\left(\mathrm{g} / \mathrm{cm}^{2} / \mathrm{yr}\right)\end{array}$ \\
\hline Post- $\mathrm{HI}_{\mathrm{HTM}}$ & $0-440$ & 4000 & 0.110 & 0.399 & 0.044 & 1062 & $4.56 \times 10^{-5}$ \\
\hline $\mathrm{HI}_{\mathrm{HTM}}$ & $440-530$ & 3800 & 0.024 & 0.379 & 0.009 & 808 & $7.36 \times 10^{-6}$ \\
\hline
\end{tabular}


Table DR2. Raw sediment geochemical data used in Figure 3 of the main article. Note

169 that some data in the figures are presented as ratios of the raw data in this table. Al data

170 are also presented to allow readers to calculate Mo/Al (as used in other studies, e.g.,

171 Jilbert and Slomp, 2013). Depth scales represent combined multi-core and gravity core

172 profiles. Blank cells $=$ no data.

\section{SR5}

\begin{tabular}{|c|c|c|c|c|c|c|c|c|}
\hline \multicolumn{5}{|c|}{ Bulk sediment elemental data } & \multicolumn{4}{|c|}{$\begin{array}{c}\text { Pigment data in } \mu \mathrm{mol} / \mathrm{g} \text { bulk } \\
\text { sediment (note independent depth } \\
\text { scale and } \mathrm{C}_{\text {org }} \text { series from bulk } \\
\text { elements) }\end{array}$} \\
\hline $\begin{array}{l}\text { Depth } \\
\mathrm{cm}\end{array}$ & $\begin{array}{c}\mathrm{C}_{\text {org }} \\
\%\end{array}$ & $\begin{array}{c}\mathrm{P} \\
p p m \\
\end{array}$ & $\begin{array}{c}\text { Mo } \\
\text { ppm } \\
\end{array}$ & $\begin{array}{l}\mathrm{Al} \\
\% \\
\end{array}$ & $\begin{array}{c}\text { Depth } \\
\mathrm{cm}\end{array}$ & $\begin{array}{c}\mathrm{C}_{\text {org }} \\
\%\end{array}$ & $\begin{array}{c}\text { Ech. } \\
\mu \mathrm{mol} / \mathrm{g}\end{array}$ & $\begin{array}{c}\text { Zeax. } \\
\mu \mathrm{mol} / \mathrm{g}\end{array}$ \\
\hline 0.25 & 2.6 & 2783 & 5 & 7.5 & 1.5 & 3.1 & 0.0014 & 0.0000 \\
\hline 0.75 & 2.6 & 2802 & 6 & 7.5 & 4.5 & 3.1 & 0.0010 & 0.0000 \\
\hline 1.25 & 2.7 & 2927 & 5 & 7.8 & 7.8 & 3.0 & 0.0008 & 0.0015 \\
\hline 1.75 & 2.7 & 2875 & 6 & 7.4 & 10.5 & 2.7 & 0.0006 & 0.0013 \\
\hline 2.50 & 2.7 & 2864 & 6 & 7.1 & 13.5 & 2.7 & 0.0009 & 0.0018 \\
\hline 3.50 & 2.8 & 2397 & 4 & 5.8 & 16.5 & 2.6 & 0.0006 & 0.0011 \\
\hline 4.50 & 2.7 & 2585 & 4 & 6.0 & 19.5 & 2.5 & 0.0006 & 0.0013 \\
\hline 5.50 & 2.5 & 2212 & 4 & 7.8 & 22.5 & 2.4 & 0.0006 & 0.0012 \\
\hline 6.50 & 2.4 & 1242 & 3 & 8.3 & 25.5 & 2.3 & 0.0005 & 0.0010 \\
\hline 7.50 & 2.3 & 1096 & 3 & 7.9 & 28.5 & 2.0 & 0.0007 & 0.0013 \\
\hline 8.50 & 2.4 & 1206 & 3 & 8.3 & 31.5 & 1.9 & 0.0005 & 0.0000 \\
\hline 9.50 & 2.4 & 1564 & 3 & 7.7 & 34.5 & 1.8 & 0.0005 & 0.0009 \\
\hline 10.50 & 2.3 & 2025 & 3 & 8.0 & 37.5 & 1.9 & 0.0005 & 0.0010 \\
\hline 12.00 & 2.3 & 1777 & 3 & 8.1 & 40.5 & 1.8 & 0.0006 & 0.0011 \\
\hline 14.00 & 2.3 & 1285 & 5 & 8.0 & 31.5 & 1.9 & 0.0004 & 0.0007 \\
\hline 16.00 & 2.2 & 1166 & 5 & 8.1 & 41.5 & 2.1 & 0.0004 & 0.0008 \\
\hline 18.00 & 2.1 & 1228 & 4 & 8.4 & 50.0 & 2.0 & 0.0004 & 0.0007 \\
\hline 20.00 & 1.3 & 1208 & 4 & 8.7 & 58.5 & 2.1 & 0.0004 & 0.0007 \\
\hline 22.00 & 1.9 & 1123 & 3 & 8.4 & 68.5 & 1.9 & 0.0004 & 0.0009 \\
\hline 24.00 & 1.6 & 1120 & 3 & 8.6 & 88.5 & 1.9 & 0.0004 & 0.0007 \\
\hline $\begin{array}{c}\text { Depth } \\
\mathrm{cm}\end{array}$ & $\begin{array}{c}\mathrm{C}_{\text {org }} \\
\% \\
\end{array}$ & $\begin{array}{c}\mathrm{P} \\
p p m \\
\end{array}$ & $\begin{array}{l}\text { Mo } \\
\text { ppm }\end{array}$ & $\begin{array}{c}\mathrm{Al} \\
\% \\
\end{array}$ & $\begin{array}{c}\text { Depth } \\
\mathrm{cm}\end{array}$ & $\begin{array}{c}\mathrm{C}_{\text {org }} \\
\% \\
\end{array}$ & $\begin{array}{c}\text { Ech. } \\
\mu \mathrm{mol} / \mathrm{g}\end{array}$ & $\begin{array}{c}\text { Zeax. } \\
\mu \mathrm{mol} / \mathrm{g}\end{array}$ \\
\hline 54.5 & 0.8 & 983 & $<2$ & 7.9 & 98.5 & 2.3 & 0.0004 & 0.0009 \\
\hline 66.5 & 0.8 & 1057 & $<2$ & 8.1 & 118.5 & 2.6 & 0.0005 & 0.0010 \\
\hline
\end{tabular}




$\begin{array}{ccccc}82.5 & 0.7 & 1074 & <2 & 8.0 \\ 90.5 & 0.9 & 805 & <2 & 5.9 \\ 98.5 & 0.9 & 961 & <2 & 7.0 \\ 112.5 & 1.0 & 965 & <2 & 6.7 \\ 126.5 & 1.2 & 1042 & <2 & 7.0 \\ 142.5 & 0.9 & 1073 & <2 & 8.1 \\ 152.5 & 1.1 & 976 & <2 & 7.0 \\ 160.5 & 1.0 & 900 & <2 & 6.6 \\ 170.5 & 0.9 & 937 & <2 & 6.6 \\ 178.5 & 0.7 & 1095 & <2 & 7.8 \\ 194.5 & 0.9 & 1022 & <2 & 7.4 \\ 210.5 & 0.8 & 1047 & <2 & 7.7 \\ 226.5 & 0.9 & 1057 & <2 & 7.8 \\ 242.5 & 0.7 & 905 & 5 & 6.9 \\ 252.5 & 0.7 & 1593 & 7 & 6.3\end{array}$

$\begin{array}{llll}128.5 & 2.6 & 0.0004 & 0.0007 \\ 148.5 & 2.5 & 0.0006 & 0.0008 \\ 158.5 & 2.5 & 0.0005 & 0.0009 \\ 178.5 & 2.5 & 0.0005 & 0.0008 \\ 188.5 & 2.5 & 0.0004 & 0.0007 \\ 208.5 & 2.3 & 0.0004 & 0.0008 \\ 218.5 & 2.3 & & \\ 228.5 & 2.2 & 0.0004 & 0.0007 \\ 238.5 & 2.3 & 0.0005 & 0.0008 \\ 248.5 & 2.6 & 0.0005 & 0.0008 \\ 258.5 & 2.3 & 0.0006 & 0.0009 \\ 268.5 & 2.2 & & \\ 278.5 & 2.3 & 0.0004 & 0.0007 \\ 288.5 & 2.3 & 0.0005 & 0.0007 \\ 308.5 & 2.4 & 0.0005 & 0.0008\end{array}$

\begin{tabular}{|c|c|c|c|c|c|c|c|c|}
\hline $\begin{array}{c}\text { Depth } \\
\mathrm{cm}\end{array}$ & $\begin{array}{c}\mathrm{C}_{\mathrm{org}} \\
\%\end{array}$ & $\begin{array}{c}\mathrm{P} \\
p p m\end{array}$ & $\begin{array}{l}\text { Mo } \\
\text { ppm }\end{array}$ & $\begin{array}{c}\mathrm{Al} \\
\%\end{array}$ & $\begin{array}{c}\text { Depth } \\
\mathrm{cm}\end{array}$ & $\begin{array}{c}\mathrm{C}_{\mathrm{org}} \\
\%\end{array}$ & $\begin{array}{c}\text { Ech. } \\
\mu \mathrm{mol} / \mathrm{g}\end{array}$ & $\begin{array}{c}\text { Zeax. } \\
\mu \mathrm{mol} / g\end{array}$ \\
\hline 258.5 & 0.7 & 869 & $<2$ & 6.3 & 318.5 & 2.3 & 0.0007 & 0.0009 \\
\hline 274.5 & 0.8 & 1211 & $<2$ & 6.7 & 338.5 & 2.7 & 0.0006 & 0.0008 \\
\hline 288.5 & 1.1 & 1523 & $<2$ & 7.3 & 348.5 & 3.0 & 0.0006 & 0.0009 \\
\hline 302.5 & 1.0 & 1183 & $<2$ & 6.6 & 354.0 & 2.8 & 0.0004 & 0.0007 \\
\hline 318.5 & 0.9 & 905 & $<2$ & 7.2 & 358.0 & 2.7 & 0.0010 & 0.0013 \\
\hline 334.5 & 0.8 & 905 & $<2$ & 7.6 & 365.0 & 2.7 & 0.0010 & 0.0012 \\
\hline 350.5 & 0.9 & 867 & $<2$ & 6.8 & 372.0 & 2.7 & 0.0011 & 0.0017 \\
\hline 353.5 & 1.0 & 1017 & $<2$ & 7.1 & 379.0 & 2.9 & 0.0008 & 0.0010 \\
\hline 357.5 & 0.9 & 988 & 9 & 8.3 & 391.0 & 2.9 & 0.0009 & 0.0007 \\
\hline 364.5 & 0.9 & 821 & $<2$ & 6.7 & 407.0 & 2.6 & 0.0012 & 0.0010 \\
\hline 371.5 & 0.9 & 927 & 6 & 7.5 & 421.0 & 3.2 & 0.0013 & 0.0015 \\
\hline 378.5 & 1.0 & 800 & 9 & 6.4 & 425.0 & 3.5 & 0.0011 & 0.0010 \\
\hline 390.5 & 1.2 & 879 & 10 & 7.2 & 430.0 & 3.5 & 0.0020 & 0.0022 \\
\hline 406.5 & 0.9 & 831 & $<2$ & 6.7 & 436.0 & 3.2 & 0.0012 & 0.0010 \\
\hline 420.5 & 1.0 & 888 & 5 & 7.2 & 442.0 & 2.8 & 0.0008 & 0.0008 \\
\hline 424.5 & 1.2 & 844 & 13 & 6.6 & 445.0 & 3.0 & 0.0014 & 0.0013 \\
\hline 429.5 & 0.9 & 952 & 19 & .78 & 449.0 & 4.7 & 0.0047 & 0.0159 \\
\hline 435.5 & 0.9 & 931 & 24 & 7.3 & 453.0 & 2.8 & 0.0016 & 0.0020 \\
\hline
\end{tabular}

\begin{tabular}{ccccccccc}
\hline $\begin{array}{c}\text { Depth } \\
\mathrm{cm}\end{array}$ & $\begin{array}{c}\mathrm{C}_{\text {org }} \\
\%\end{array}$ & $\begin{array}{c}\mathrm{P} \\
\mathrm{ppm}\end{array}$ & $\begin{array}{c}\mathrm{Mo} \\
\mathrm{ppm}\end{array}$ & $\begin{array}{c}\mathrm{Al} \\
\%\end{array}$ & $\begin{array}{c}\text { Depth } \\
\mathrm{cm}\end{array}$ & $\begin{array}{c}\mathrm{C}_{\text {org }} \\
\%\end{array}$ & $\begin{array}{c}\text { Ech. } \\
\mu \mathrm{mol} / \mathrm{g}\end{array}$ & $\begin{array}{c}\text { Zeax. } \\
\mu m o l / g\end{array}$ \\
\hline & & & & & & & & \\
441.5 & 0.9 & 928 & 20 & 7.8 & 455.0 & & 0.0486 & 0.1888 \\
444.5 & 1.1 & 825 & 21 & 6.6 & 459.0 & 3.1 & 0.0015 & 0.0017 \\
448.5 & 2.1 & 825 & 52 & 6.0 & 463.0 & 2.8 & 0.0020 & 0.0026 \\
452.5 & 0.8 & 907 & 15 & 7.6 & 469.0 & 3.2 & 0.0021 & 0.0027 \\
454.5 & 1.0 & 692 & 6 & 5.8 & 473.0 & 3.6 & 0.0008 & 0.0014
\end{tabular}




$\begin{array}{lllllllll}458.5 & 1.1 & 983 & 11 & 7.9 & 475.0 & 4.5 & 0.0043 & 0.0082 \\ 462.5 & 1.0 & 766 & 13 & 6.1 & 477.0 & 5.4 & 0.0122 & 0.0279 \\ 468.5 & 1.2 & 947 & 24 & 8.0 & 479.0 & 5.4 & 0.0087 & 0.0216 \\ 472.5 & 1.2 & 930 & 40 & 7.3 & 481.0 & 3.2 & 0.0037 & 0.0056 \\ 474.5 & 2.0 & 844 & 61 & 6.4 & 483.0 & 6.7 & 0.0124 & 0.0242 \\ 476.5 & 1.7 & 823 & 36 & 6.6 & 485.0 & 7.7 & 0.0219 & 0.0484 \\ 478.5 & 1.2 & 914 & 22 & 7.8 & 487.0 & 6.2 & 0.0175 & 0.0336 \\ 480.5 & 1.9 & 892 & 68 & 6.8 & 489.0 & 6.0 & 0.0092 & 0.0120 \\ 482.5 & 3.1 & 793 & 101 & 5.1 & 491.0 & 4.4 & 0.0063 & 0.0111 \\ 484.5 & 3.0 & 806 & 75 & 5.7 & 494.0 & 5.1 & 0.0101 & 0.0190 \\ 486.5 & 2.7 & 953 & 116 & 6.5 & 496.0 & 6.7 & 0.0168 & 0.0288 \\ 488.5 & 2.1 & 815 & 36 & 6.7 & 497.0 & 5.3 & 0.0130 & 0.0217 \\ 490.5 & 1.2 & 838 & 21 & 7.0 & 500.0 & 8.8 & 0.0285 & 0.0543 \\ 493.5 & 2.7 & 804 & 72 & 5.9 & 502.0 & 8.3 & 0.0236 & 0.0463 \\ 495.5 & 2.2 & 822 & 76 & 6.6 & 504.0 & 11.2 & 0.0303 & 0.0869 \\ 496.5 & 2.3 & 789 & 95 & 5.9 & 505.0 & 10.5 & 0.0243 & 0.0728\end{array}$

\begin{tabular}{|c|c|c|c|c|c|c|c|c|}
\hline $\begin{array}{c}\text { Depth } \\
\mathrm{cm}\end{array}$ & $\begin{array}{c}\mathrm{C}_{\mathrm{org}} \\
\% \\
\end{array}$ & $\begin{array}{c}\mathrm{P} \\
p p m\end{array}$ & $\begin{array}{l}\text { Mo } \\
\text { ppm }\end{array}$ & $\begin{array}{c}\mathrm{Al} \\
\%\end{array}$ & $\begin{array}{c}\text { Depth } \\
\mathrm{cm}\end{array}$ & $\begin{array}{c}\mathrm{C}_{\text {org }} \\
\%\end{array}$ & $\begin{array}{c}\text { Ech. } \\
\mu m o l / g\end{array}$ & $\begin{array}{c}\text { Zeax. } \\
\mu m o l / g\end{array}$ \\
\hline 499.5 & 2.0 & 787 & 105 & 6.1 & 507.0 & 13.2 & 0.1114 & 0.1314 \\
\hline 501.5 & 5.3 & 981 & & 5.2 & 509.0 & 15.3 & 0.0937 & 0.3126 \\
\hline 503.5 & 3.6 & 761 & 174 & 5.0 & 510.0 & 11.8 & 0.0698 & 0.1498 \\
\hline 504.5 & 4.8 & 711 & 181 & 4.0 & 512.0 & 12.4 & 0.0647 & 0.1569 \\
\hline 506.5 & 6.2 & 751 & 189 & 3.0 & 513.0 & 11.1 & 0.0520 & 0.1434 \\
\hline 508.5 & 4.9 & 776 & 206 & 4.2 & 515.0 & 11.7 & 0.0891 & 0.2032 \\
\hline 509.5 & 3.3 & 783 & 142 & 5.0 & 516.0 & 12.8 & 0.1644 & 0.3043 \\
\hline 511.5 & 6.3 & 653 & 120 & 3.5 & 519.0 & 16.0 & 0.1402 & 0.3188 \\
\hline 512.5 & 5.5 & 534 & 118 & 2.7 & 521.0 & 18.3 & 0.3514 & 0.3870 \\
\hline 514.5 & 5.7 & 593 & 156 & 2.6 & 524.0 & 14.7 & 0.1192 & 0.1535 \\
\hline 516.5 & 7.0 & 420 & 128 & 1.7 & 526.0 & 15.5 & 0.1266 & 0.1976 \\
\hline 519.5 & 10.0 & 529 & 177 & 1.9 & 529.0 & 17.8 & 0.1402 & 0.2942 \\
\hline 521.5 & 6.8 & 707 & 250 & 3.1 & 531.0 & 17.1 & 0.1240 & 0.4814 \\
\hline 524.5 & 11.7 & 619 & 188 & 2.9 & 533.0 & 9.4 & 0.0281 & 0.1323 \\
\hline 526.5 & 6.4 & 859 & 237 & 4.3 & 537.0 & 2.0 & 0.0004 & 0.0008 \\
\hline 528.5 & 5.9 & 668 & 190 & 2.3 & 540.0 & 2.5 & 0.0000 & 0.0021 \\
\hline 530.5 & 10.4 & 815 & 240 & 3.4 & 544.0 & 2.5 & 0.0004 & 0.0008 \\
\hline 532.5 & 1.0 & 815 & 30 & 6.3 & 548.0 & 2.3 & 0.0004 & 0.0009 \\
\hline 536.5 & 0.7 & 679 & 11 & 6.1 & 553.0 & 3.0 & 0.0003 & 0.0008 \\
\hline $\begin{array}{c}\text { Depth } \\
\mathrm{cm}\end{array}$ & $\begin{array}{c}\mathrm{C}_{\text {org }} \\
\% \\
\end{array}$ & $\begin{array}{c}\mathrm{P} \\
p p m\end{array}$ & $\begin{array}{c}\text { Mo } \\
\text { ppm }\end{array}$ & $\begin{array}{l}\mathrm{Al} \\
\%\end{array}$ & $\begin{array}{c}\text { Depth } \\
\mathrm{cm}\end{array}$ & $\begin{array}{c}\mathrm{C}_{\text {org }} \\
\%\end{array}$ & $\begin{array}{c}\text { Ech. } \\
\mu \mathrm{mol} / \mathrm{g}\end{array}$ & $\begin{array}{c}\text { Zeax. } \\
\mu \mathrm{mol} / \mathrm{g}\end{array}$ \\
\hline 540.5 & 0.9 & 816 & 13 & 6.9 & & & & \\
\hline 544.5 & 1.0 & 863 & 12 & 7.2 & & & & \\
\hline
\end{tabular}




$\begin{array}{lllll}548.5 & 0.8 & 840 & <2 & 6.7 \\ 552.5 & 1.0 & 697 & <2 & 5.6\end{array}$

\section{LL19}

\section{Bulk sediment elemental data}

\begin{tabular}{|c|c|c|c|c|c|c|c|c|}
\hline & & & & & \multicolumn{4}{|c|}{ series from bulk elements) } \\
\hline $\begin{array}{c}\text { Depth } \\
\mathrm{cm}\end{array}$ & $\begin{array}{c}C_{\text {org }} \\
\% \\
\end{array}$ & $\begin{array}{c}\mathrm{P} \\
\text { ppm }\end{array}$ & $\begin{array}{c}\text { Mo } \\
\text { ppm }\end{array}$ & $\begin{array}{l}\mathrm{Al} \\
\% \\
\end{array}$ & $\begin{array}{c}\text { Depth } \\
\mathrm{cm}\end{array}$ & $\begin{array}{c}\mathrm{C}_{\text {org }} \\
\%\end{array}$ & $\begin{array}{c}\text { Ech. } \\
\mu \mathrm{mol} / \mathrm{g}\end{array}$ & $\begin{array}{c}\text { Zeax. } \\
\mu \mathrm{mol} / \mathrm{g}\end{array}$ \\
\hline 0.25 & 11.83 & 1709 & 155 & 5.3 & 5.5 & 9.72 & 0.0133 & 0.0466 \\
\hline 0.75 & 13.65 & 1794 & 216 & 5.1 & 7.5 & 8.38 & 0.0099 & 0.0375 \\
\hline 1.25 & 12.87 & 1709 & 206 & 5.2 & 9.5 & 2.79 & 0.0009 & 0.0026 \\
\hline 1.75 & 11.68 & 1570 & 196 & 5.6 & 11.5 & 2.46 & 0.0015 & 0.0030 \\
\hline 2.50 & 9.82 & 1345 & 159 & 6.1 & 13.5 & 2.15 & 0.0013 & 0.0025 \\
\hline 3.50 & 8.83 & 1284 & 160 & 6.4 & 15.5 & 2.10 & 0.0010 & 0.0019 \\
\hline 4.50 & 8.44 & 1252 & 167 & 6.3 & 17.5 & 2.10 & 0.0010 & 0.0025 \\
\hline 5.50 & 8.47 & 1370 & 160 & 6.1 & 19.5 & 2.01 & 0.0010 & 0.0020 \\
\hline 6.50 & 7.59 & 1277 & 181 & 6.3 & 21.5 & 2.00 & 0.0011 & 0.0022 \\
\hline 7.50 & 7.73 & 1194 & 221 & 6.4 & 23.5 & 1.97 & 0.0010 & 0.0019 \\
\hline 8.50 & 7.18 & 1056 & 122 & 5.9 & 25.5 & 2.02 & 0.0011 & 0.0019 \\
\hline 9.50 & 3.74 & 961 & 24 & 7.6 & 27.5 & 2.08 & 0.0010 & 0.0020 \\
\hline 11.00 & 2.87 & 872 & 11 & 8.7 & 29.5 & 2.16 & 0.0011 & 0.0020 \\
\hline 13.00 & 2.48 & 849 & 11 & 8.8 & 31.5 & 2.23 & 0.0011 & 0.0020 \\
\hline 15.00 & 2.21 & 860 & 11 & 9.1 & 33.5 & 2.27 & 0.0011 & 0.0019 \\
\hline 17.00 & 1.42 & 795 & 8 & 8.6 & 35.5 & 2.25 & 0.0012 & 0.0020 \\
\hline 19.00 & 1.88 & 775 & 8 & 8.3 & 37.5 & 2.25 & 0.0006 & 0.0013 \\
\hline 21.00 & 1.83 & 791 & 6 & 8.7 & 39.5 & 2.13 & 0.0011 & 0.0021 \\
\hline 23.00 & 1.57 & 816 & 5 & 8.9 & 41.5 & 2.10 & 0.0010 & 0.0019 \\
\hline 25.00 & 1.96 & 838 & 5 & 8.9 & 43.5 & 2.11 & 0.0010 & 0.0017 \\
\hline 27.00 & 2.08 & 821 & $<2$ & 8.4 & 45.5 & 2.15 & 0.0009 & 0.0016 \\
\hline
\end{tabular}

\begin{tabular}{ccccccccc}
\hline $\begin{array}{c}\text { Depth } \\
\text { cm }\end{array}$ & $\begin{array}{c}\mathrm{C}_{\text {org }} \\
\%\end{array}$ & $\begin{array}{c}\mathrm{P} \\
p p m\end{array}$ & $\begin{array}{c}\mathrm{Mo} \\
p p m\end{array}$ & $\begin{array}{c}\mathrm{Al} \\
\%\end{array}$ & $\begin{array}{c}\text { Depth } \\
\mathrm{cm}\end{array}$ & $\begin{array}{c}\mathrm{C}_{\text {org }} \\
\%\end{array}$ & $\begin{array}{c}\text { Ech. } \\
\mu \mathrm{mol} / \mathrm{g}\end{array}$ & $\begin{array}{c}\text { Zeax. } \\
\mu m o l / g\end{array}$ \\
\hline & & & & & & & & \\
29.00 & 2.01 & 804 & 5 & 8.4 & 68.5 & 2.5 & 0.0004 & 0.0005 \\
31.00 & 1.99 & 856 & 7 & 8.8 & 70.5 & 2.6 & 0.0005 & 0.0005 \\
33.00 & 1.92 & 821 & 9 & 8.5 & 72.5 & 2.5 & 0.0005 & 0.0008 \\
35.00 & 1.80 & 786 & 8 & 8.1 & 74.5 & 2.7 & 0.0008 & 0.0022 \\
37.00 & 1.84 & 825 & 11 & 8.5 & 76.5 & 3.0 & 0.0007 & 0.0013 \\
39.00 & 2.01 & 846 & 8 & 8.7 & 77.5 & 3.0 & 0.0007 & 0.0011 \\
41.00 & 1.88 & 837 & 17 & 8.8 & 79.5 & 3.2 & 0.0011 & 0.0022 \\
43.00 & 1.93 & 764 & 5 & 8.3 & 81.5 & 2.9 & 0.0015 & 0.0044 \\
& & & & & & & &
\end{tabular}




$\begin{array}{lcccccccc}45.00 & 1.93 & 819 & 8 & 8.7 & 83.5 & 3.0 & 0.0011 & 0.0037 \\ 47.00 & 1.94 & 841 & 14 & 8.9 & 86.5 & 3.0 & 0.0015 & 0.0031 \\ 49.00 & 1.85 & 793 & 13 & 8.5 & 88.5 & 4.3 & 0.0040 & 0.0200 \\ 51.00 & 1.92 & 750 & 6 & 8.2 & 90.5 & 8.4 & 0.0195 & 0.0754 \\ 53.00 & 1.95 & 777 & 8 & 8.3 & 92.5 & 7.5 & 0.0153 & 0.0639 \\ 55.00 & 2.00 & 777 & 12 & 8.0 & 94.5 & 6.8 & 0.0117 & 0.0434 \\ 56.50 & 2.03 & 834 & 20 & 8.6 & 96.5 & 5.8 & 0.0089 & 0.0385 \\ 57.50 & 2.17 & 789 & 24 & 7.9 & 98.5 & 3.5 & 0.0033 & 0.0118 \\ 58.50 & 2.15 & 762 & 28 & 7.9 & 100.5 & 3.3 & 0.0039 & 0.0169\end{array}$

\begin{tabular}{|c|c|c|c|c|c|c|c|c|}
\hline $\begin{array}{c}\text { Depth } \\
\mathrm{cm}\end{array}$ & $\begin{array}{c}\mathrm{C}_{\text {org }} \\
\% \\
\end{array}$ & $\begin{array}{c}\mathrm{P} \\
p p m \\
\end{array}$ & $\begin{array}{c}\text { Mo } \\
\text { ppm }\end{array}$ & $\begin{array}{c}\mathrm{Al} \\
\% \\
\end{array}$ & $\begin{array}{c}\text { Depth } \\
\mathrm{cm}\end{array}$ & $\begin{array}{c}\mathrm{C}_{\mathrm{org}} \\
\% \\
\end{array}$ & $\begin{array}{c}\text { Ech. } \\
\mu \mathrm{mol} / \mathrm{g}\end{array}$ & $\begin{array}{c}\text { Zeax. } \\
\mu \mathrm{mol} / g\end{array}$ \\
\hline 59.50 & 2.26 & 800 & 30 & $8-4$ & 102.5 & 4.9 & 0.0082 & 0.0353 \\
\hline 60.50 & 2.19 & 825 & 18 & 8.6 & 104.5 & 3.8 & 0.0040 & 0.0158 \\
\hline 61.50 & 2.20 & 842 & 20 & 8.7 & 106.5 & 3.4 & 0.0037 & 0.0153 \\
\hline 62.50 & 2.15 & 784 & 22 & 8.1 & 109.5 & 2.2 & 0.0012 & 0.0034 \\
\hline 63.50 & 2.21 & 728 & 15 & 7.7 & 124.0 & 2.2 & 0.0012 & 0.0010 \\
\hline 64.50 & 2.18 & 800 & 23 & 8.2 & 144.0 & 1.8 & 0.0007 & 0.0012 \\
\hline 65.50 & 2.08 & 746 & 13 & 7.9 & 164.0 & 1.9 & 0.0007 & 0.0011 \\
\hline 66.50 & 2.17 & 699 & 12 & 7.1 & 174.0 & 2.0 & 0.0010 & 0.0029 \\
\hline 67.50 & 2.07 & 752 & 23 & 7.2 & 184.0 & 2.0 & 0.0009 & 0.0016 \\
\hline 68.50 & 2.23 & 694 & 13 & 7.2 & 204.0 & 1.9 & 0.0006 & 0.0009 \\
\hline 69.50 & 2.22 & 710 & 14 & 7.5 & 214.0 & 2.1 & 0.0018 & 0.0013 \\
\hline 70.50 & 2.37 & 785 & 19 & 8.0 & 224.0 & 2.0 & 0.0012 & 0.0024 \\
\hline 71.50 & 2.19 & 781 & 13 & 8.1 & 234.0 & 1.9 & 0.0007 & 0.0007 \\
\hline 72.50 & 2.31 & 734 & 10 & 7.6 & 244.0 & 2.0 & 0.0013 & 0.0031 \\
\hline 73.50 & 2.11 & 816 & 17 & 8.0 & 254.0 & 2.2 & 0.0021 & 0.0070 \\
\hline 74.50 & 2.21 & 998 & 12 & 7.2 & 262.0 & 2.1 & 0.0026 & 0.0071 \\
\hline 75.50 & 2.14 & 840 & $<2$ & 6.7 & 265.5 & 2.3 & 0.0013 & 0.0034 \\
\hline 77.00 & 2.31 & 706 & $<2$ & 6.1 & 266.5 & 2.1 & 0.0010 & 0.0014 \\
\hline 79.00 & 2.52 & 638 & 20 & 6.1 & 267.5 & 2.3 & 0.0012 & 0.0023 \\
\hline $\begin{array}{c}\text { Depth } \\
\mathrm{cm}\end{array}$ & $\begin{array}{c}\mathrm{C}_{\text {org }} \\
\%\end{array}$ & $\begin{array}{c}\mathrm{P} \\
p p m\end{array}$ & $\begin{array}{l}\text { Mo } \\
\text { ppm }\end{array}$ & $\begin{array}{l}\mathrm{Al} \\
\%\end{array}$ & $\begin{array}{c}\text { Depth } \\
\mathrm{cm}\end{array}$ & $\begin{array}{c}\mathrm{C}_{\mathrm{org}} \\
\%\end{array}$ & $\begin{array}{c}\text { Ech. } \\
\mu \mathrm{mol} / \mathrm{g}\end{array}$ & $\begin{array}{c}\text { Zeax. } \\
\mu \mathrm{mol} / g\end{array}$ \\
\hline 81.00 & 2.37 & 648 & 20 & 6.4 & 268.5 & 2.5 & 0.0015 & 0.0029 \\
\hline 83.00 & 2.33 & 737 & 18 & 6.7 & 270.5 & 4.0 & 0.0050 & 0.0203 \\
\hline 85.00 & 2.52 & 848 & 17 & 8.7 & 272.5 & 4.5 & 0.0037 & 0.0169 \\
\hline 86.50 & 2.71 & 879 & 23 & 8.7 & 274.5 & 5.0 & 0.0064 & 0.0314 \\
\hline 87.50 & 2.79 & 875 & 23 & 8.6 & 276.5 & 8.0 & 0.0107 & 0.0458 \\
\hline 88.50 & 3.46 & 865 & 28 & 8.2 & 278.5 & 7.9 & 0.0200 & 0.0700 \\
\hline 89.50 & 4.93 & 938 & 124 & 8.0 & 280.5 & 5.3 & 0.0104 & 0.0383 \\
\hline 90.50 & 7.49 & 928 & 254 & 6.5 & 282.5 & 3.5 & 0.0033 & 0.0166 \\
\hline 91.50 & 6.57 & 936 & 245 & 6.6 & 284.5 & 5.8 & 0.0056 & 0.0245 \\
\hline 92.50 & 5.15 & 886 & 135 & 7.2 & 286.5 & 5.3 & 0.0063 & 0.0237 \\
\hline
\end{tabular}




$\begin{array}{ccccccccc}93.50 & 5.30 & 894 & 112 & 7.3 & 288.5 & 3.8 & 0.0032 & 0.0126 \\ 94.50 & 4.29 & 1025 & 79 & 9.2 & 290.5 & 6.1 & 0.0068 & 0.0291 \\ 95.50 & 4.73 & 857 & 52 & 7.2 & 292.5 & 6.2 & 0.0120 & 0.0319 \\ 96.50 & 4.37 & 813 & 59 & 6.9 & 294.5 & 3.8 & 0.0041 & 0.0121 \\ 97.50 & 3.00 & & & & 296.5 & 2.0 & 0.0011 & 0.0020 \\ 98.50 & 3.37 & & & & 298.5 & 1.7 & 0.0005 & 0.0005 \\ 99.50 & 3.33 & 889 & 15 & 8.0 & 300.5 & 2.2 & 0.0010 & 0.0007 \\ 100.50 & 3.21 & 838 & 16 & 8.0 & 302.5 & 4.4 & 0.0083 & 0.0200 \\ 101.50 & 3.48 & 885 & 16 & 8.6 & 304.5 & 2.1 & 0.0018 & 0.0021\end{array}$

\begin{tabular}{ccccccccc}
\hline Depth & $\begin{array}{c}\mathrm{C}_{\text {org }} \\
\text { cm }\end{array}$ & $\begin{array}{c}\mathrm{P} \\
\text { \%pm }\end{array}$ & $\begin{array}{c}\text { Mo } \\
p p m\end{array}$ & $\begin{array}{c}\mathrm{Al} \\
\%\end{array}$ & $\begin{array}{c}\text { Depth } \\
\mathrm{cm}\end{array}$ & $\begin{array}{c}\mathrm{C}_{\text {org }} \\
\%\end{array}$ & $\begin{array}{c}\text { Ech. } \\
\mu m o l / g\end{array}$ & $\begin{array}{c}\text { Zeax. } \\
\mu m o l / g\end{array}$ \\
\hline 102.50 & 3.68 & 838 & 17 & 7.7 & & & & \\
103.50 & 3.41 & 867 & 20 & 7.6 & 306.5 & 2.2 & 0.0016 & 0.0020 \\
104.50 & 3.93 & 793 & 29 & 7.1 & 308.5 & 3.3 & 0.0068 & 0.0131 \\
105.50 & 3.71 & 836 & 25 & 7.9 & 310.5 & 3.0 & 0.0036 & 0.0052 \\
106.50 & 3.16 & 753 & 17 & 7.3 & 312.5 & 10.3 & 0.0399 & 0.0994 \\
107.50 & 3.03 & 860 & 17 & 8.4 & 314.5 & 2.6 & 0.0005 & 0.0005 \\
108.50 & 2.40 & 810 & 8 & 8.5 & 316.5 & 1.9 & 0.0004 & 0.0000 \\
109.50 & 2.08 & 799 & 6 & 8.8 & 318.5 & 2.4 & 0.0008 & 0.0012 \\
110.50 & 1.98 & 765 & 7 & 8.4 & 320.5 & 3.0 & 0.0016 & 0.0026 \\
122.00 & 1.76 & 780 & 5 & 8.6 & 322.5 & 3.3 & 0.0009 & 0.0019 \\
134.00 & 2.11 & 781 & 6 & 8.4 & 326.5 & 3.3 & 0.0009 & 0.0021 \\
146.00 & 2.23 & 800 & 10 & 8.5 & 328.5 & 3.2 & 0.0005 & 0.0008 \\
158.00 & 1.74 & 773 & 6 & 8.8 & 329.5 & 3.4 & 0.0005 & 0.0015 \\
170.00 & 1.82 & 739 & $<2$ & 8.3 & 331.5 & 2.8 & 0.0004 & 0.0013 \\
182.00 & 1.87 & 808 & 4 & 8.9 & 333.5 & 2.4 & 0.0004 & 0.0009 \\
194.00 & 2.11 & 806 & 8 & 9.0 & 335.5 & 2.3 & 0.0003 & 0.0005 \\
204.00 & 1.86 & 789 & 4 & 8.8 & 337.5 & 1.9 & 0.0004 & 0.0005 \\
& & & & & 339.5 & 1.6 & 0.0003 & 0.0000 \\
\hline
\end{tabular}

\begin{tabular}{ccccccccc}
\hline $\begin{array}{c}\text { Depth } \\
c m\end{array}$ & $\begin{array}{c}\mathrm{C}_{\text {org }} \\
\%\end{array}$ & $\begin{array}{c}\mathrm{P} \\
p p m\end{array}$ & $\begin{array}{c}\mathrm{Mo} \\
\mathrm{p} m\end{array}$ & $\begin{array}{c}\mathrm{Al} \\
\%\end{array}$ & $\begin{array}{c}\text { Depth } \\
\mathrm{cm}\end{array}$ & $\begin{array}{c}\mathrm{C}_{\text {org }} \\
\%\end{array}$ & $\begin{array}{c}\text { Ech. } \\
\mu m o l / g\end{array}$ & $\begin{array}{c}\text { Zeax. } \\
\mu m o l / g\end{array}$ \\
\hline & & & & & & & & \\
216.00 & 1.80 & 842 & 7 & 9.2 & 342.5 & 1.0 & 0.0000 & 0.0000 \\
228.00 & 1.73 & 735 & 2 & 8.4 & 343.5 & 1.2 & 0.0000 & 0.0000 \\
240.00 & 1.63 & 777 & 4 & 8.9 & 345.5 & 1.2 & 0.0000 & 0.0000 \\
242.00 & 1.67 & 713 & 3 & 8.2 & 347.5 & 1.1 & 0.0000 & 0.0000 \\
244.00 & 1.78 & 807 & 4 & 9.2 & 349.5 & 0.9 & 0.0000 & 0.0000 \\
246.00 & 1.75 & 777 & 6 & 8.9 & 354.5 & 1.1 & 0.0000 & 0.0000 \\
248.00 & 1.83 & 823 & 4 & 9.2 & 355.5 & 1.1 & 0.0000 & 0.0005 \\
250.00 & 1.82 & 822 & 5 & 9.2 & 357.5 & 1.0 & 0.0000 & 0.0005 \\
252.00 & 1.97 & 640 & 6 & 7.3 & 359.5 & 1.0 & 0.0000 & 0.0000 \\
254.00 & 2.30 & 743 & 7 & 8.1 & 361.5 & 1.0 & 0.0000 & 0.0005 \\
256.00 & 1.87 & 809 & 6 & 9.1 & 363.5 & 1.0 & 0.0000 & 0.0000 \\
258.00 & 2.10 & 796 & 7 & 8.5 & 366.5 & 0.8 & 0.0000 & 0.0004
\end{tabular}




$\begin{array}{lllllllll}260.00 & 1.94 & 779 & 6 & 8.9 & 367.5 & 0.9 & 0.0000 & 0.0000 \\ 262.00 & 1.94 & 811 & 8 & 8.6 & 374.0 & 0.9 & 0.0000 & 0.0000 \\ 264.00 & 2.01 & 733 & 9 & 8.0 & 384.0 & 0.8 & 0.0000 & 0.0004 \\ 265.50 & 2.11 & 812 & 10 & 8.7 & 394.0 & 0.5 & 0.0000 & 0.0004 \\ 266.50 & 1.89 & 818 & 7 & 8.9 & & & & \\ 267.50 & 2.00 & 807 & 6 & 8.8 & & & & \\ 268.50 & & 820 & 9 & 8.8 & & & \end{array}$

\begin{tabular}{ccccc}
\hline Depth & $\mathrm{C}_{\text {org }}$ & $\mathrm{P}$ & $\mathrm{Mo}$ & $\mathrm{Al}$ \\
$\mathrm{cm}$ & $\%$ & ppm & ppm & $\%$ \\
\hline
\end{tabular}

$\begin{array}{ccccc}269.50 & 2.93 & 784 & 15 & 8.1 \\ 270.50 & 3.16 & 820 & 26 & 8.2 \\ 271.50 & 3.37 & 791 & 22 & 8.0 \\ 272.50 & 3.51 & 848 & 32 & 8.1 \\ 273.50 & 4.77 & 832 & 115 & 7.3 \\ 274.50 & 4.30 & 1028 & 71 & 7.9 \\ 275.50 & 6.67 & 904 & 205 & 7.0 \\ 276.50 & 5.88 & 853 & 152 & 7.1 \\ 277.50 & 7.91 & 849 & 246 & 6.4 \\ 278.50 & 6.41 & 868 & 224 & 7.0 \\ 279.50 & 5.09 & 839 & 160 & 7.7 \\ 280.50 & 4.94 & 779 & 103 & 7.2 \\ 281.50 & 4.22 & 854 & 44 & 8.1 \\ 282.50 & 3.43 & 833 & 40 & 8.1 \\ 283.50 & 3.69 & 768 & 29 & 7.9 \\ 284.50 & 4.68 & 774 & 72 & 7.1 \\ 285.50 & 4.85 & 795 & 81 & 7.4 \\ 286.50 & 3.94 & 847 & 35 & 8.4\end{array}$

\begin{tabular}{ccccc}
\hline Depth & $\mathrm{C}_{\text {org }}$ & $\mathrm{P}$ & $\mathrm{Mo}$ & $\mathrm{Al}$ \\
$\mathrm{cm}$ & $\%$ & ppm & ppm & $\%$ \\
\hline
\end{tabular}

$\begin{array}{lllll}287.50 & 4.59 & 829 & 76 & 7.7 \\ 288.50 & 3.61 & 678 & 35 & 7.1 \\ 289.50 & 3.21 & 776 & 24 & 8.1 \\ 290.50 & 4.84 & 793 & 66 & 7.4 \\ 291.50 & 4.44 & 749 & 63 & 7.2 \\ 292.50 & 5.41 & 802 & 99 & 7.3 \\ 293.50 & 4.58 & 789 & 61 & 7.9 \\ 294.50 & 2.74 & 800 & 33 & 8.6 \\ 295.50 & 1.75 & 664 & 5 & 8.0 \\ 296.50 & 1.90 & 683 & 7 & 7.9 \\ 297.50 & 1.67 & 727 & 11 & 7.7 \\ 298.50 & 1.57 & 740 & 15 & 8.3 \\ 299.50 & 1.73 & 843 & 12 & 9.1\end{array}$




$\begin{array}{lllll}300.50 & 2.06 & 781 & 15 & 9.0 \\ 301.50 & 2.52 & 744 & 24 & 8.4 \\ 302.50 & 3.82 & 828 & 48 & 8.4 \\ 303.50 & 2.48 & 810 & 19 & 8.3 \\ 304.50 & 2.10 & 742 & 14 & 8.5\end{array}$

\begin{tabular}{ccccc}
\hline Depth & $\begin{array}{c}\mathrm{C}_{\text {org }} \\
\text { cm }\end{array}$ & $\begin{array}{c}\mathrm{P} \\
\text { \% }\end{array}$ & $\begin{array}{c}\text { Mo } \\
p p m\end{array}$ & $\begin{array}{c}\mathrm{Al} \\
\%\end{array}$ \\
\hline & & & & \\
305.50 & 2.15 & 753 & 12 & 8.4 \\
306.50 & 1.98 & 746 & 17 & 8.5 \\
307.50 & 2.39 & 772 & 18 & 8.5 \\
308.50 & 3.28 & 788 & 35 & 8.1 \\
309.50 & 2.43 & 788 & 32 & 8.5 \\
310.50 & 5.03 & 790 & 99 & 7.4 \\
311.50 & 8.02 & 874 & 237 & 6.8 \\
312.50 & 8.36 & 858 & 267 & 6.6 \\
313.50 & 6.54 & 887 & 212 & 7.0 \\
314.50 & 1.77 & 809 & 26 & 7.6 \\
315.50 & 1.75 & 897 & 32 & 8.3 \\
316.50 & 1.81 & 779 & 16 & 8.5 \\
317.50 & 1.95 & 764 & 16 & 8.6 \\
318.50 & 1.94 & 784 & 32 & 7.6 \\
319.50 & 2.50 & 829 & 14 & 8.8 \\
320.50 & 3.19 & 796 & 16 & 8.3 \\
321.50 & 3.71 & 772 & 24 & 8.0 \\
322.50 & 2.69 & 797 & 23 & 8.6 \\
323.50 & 3.33 & 818 & 20 & 7.9
\end{tabular}

\begin{tabular}{ccccc}
\hline Depth & $\mathrm{C}_{\text {org }}$ & $\mathrm{P}$ & $\mathrm{Mo}$ & $\mathrm{Al}$ \\
$\mathrm{cm}$ & $\%$ & $p p m$ & $\mathrm{ppm}$ & $\%$ \\
\hline
\end{tabular}

$\begin{array}{lllll}324.50 & 2.76 & 936 & 19 & 8.2 \\ 325.50 & 2.84 & 925 & 28 & 7.9 \\ 327.00 & 2.55 & 824 & 35 & 8.3 \\ 329.00 & 2.70 & 766 & 39 & 7.6 \\ 331.00 & 2.35 & 795 & 17 & 7.7 \\ 333.00 & 2.07 & 824 & 10 & 8.9 \\ 337.00 & 1.92 & 816 & 4 & 9.0 \\ 339.00 & 1.40 & 736 & <2 & 9.1 \\ 343.00 & 0.90 & 547 & <2 & 7.7 \\ 345.00 & & 652 & <2 & 9.2 \\ 349.00 & 0.88 & 659 & <2 & 9.2 \\ 353.00 & 0.82 & 672 & <2 & 9.3 \\ 355.00 & 0.99 & 592 & <2 & 8.5 \\ 357.00 & 0.88 & 674 & <2 & 9.5\end{array}$




\begin{tabular}{ccccc}
361.00 & 0.88 & 645 & $<2$ & 9.1 \\
365.00 & 0.73 & 667 & 2 & 9.6 \\
367.00 & 0.91 & 639 & $<2$ & 9.3 \\
369.00 & 0.52 & 653 & 2 & 9.1 \\
& & & & \\
\hline Depth & $\mathrm{C}_{\text {org }}$ & $\mathrm{P}$ & Mo & $\mathrm{Al}$ \\
$c m$ & $\%$ & $p p m$ & $p p m$ & $\%$ \\
\hline & & & & \\
373.00 & 1.09 & 667 & $<2$ & 9.2 \\
377.00 & 0.66 & 669 & $<2$ & 9.3 \\
379.00 & & 645 & $<2$ & 9.0 \\
381.00 & 0.65 & 727 & $<2$ & 9.9 \\
385.00 & 0.57 & 710 & $<2$ & 9.5 \\
389.00 & 0.43 & 708 & 2 & 9.5 \\
391.00 & 0.55 & 676 & $<2$ & 9.2 \\
393.00 & 0.52 & 700 & 2 & 9.6 \\
397.50 & 0.53 & 763 & 2 & 10.1 \\
& & & & \\
\hline
\end{tabular}

\section{SUPPLEMENTARY REFERENCES}

175 Bronk Ramsey, C. B., 2009, Bayesian Analysis of Radiocarbon Dates: Radiocarbon, v. 51, no. 1 , p. 337-360.

177 Funkey, C. P., Conley, D. J., Reuss, N. S., Humborg, C., Jilbert, T., and Slomp, C. P., 2014, Hypoxia sustains cyanobacteria blooms in the Baltic Sea: Environmental Science \& Technology, v. 48, no. 5, p. 2598-2602.

180 Jilbert, T. and Slomp, C.P., 2013, Rapid high-amplitude variability in Baltic Sea hypoxia during the Holocene: Geology, v. 41, p. 1183-1186. Wacker, L., 2012a, Using an independent geochronology based on palaeomagnetic secular variation (PSV) and atmospheric $\mathrm{Pb}$ deposition to date Baltic Sea sediments and infer C-14 reservoir age: Quaternary Science Reviews, v. 42, p. 43-58. 
Lougheed, B.C., Filipsson, H.L. and Snowball, I., 2012b, Large spatial variations in coastal C-14 reservoir age: A case study from the Baltic Sea. Climate of the Past, v. 9, p. $1015-1028$.

Påsse, T. and Andersson, L., 2005, Shore-level displacement in Fennoscandia calculated from empirical data. GFF, v. 127, p. 253-268.

Savchuk, O.P., 2005, Resolving the Baltic Sea into seven subbasins: N and P budgets for 1991-1999: Journal of Marine Systems, v. 56, no. 1-2, p. 1-15.

Slomp, C.P., Mort, H.P., Jilbert, T., Reed, D.C., Gustafsson, B.G., and Wolthers, M., 2013, Coupled dynamics of iron and phosphorus in sediments of an oligotrophic coastal basin and the impact of anaerobic oxidation of methane: PLoS ONE, v. 8, no. 4, p. e62386. 